\title{
Interacciones de corales masivos con céspedes algales y otros organismos en arrecifes del Parque Nacional Natural Tayrona
}

\section{Interactions of massive corals with turf algae and other reef organisms in Tayrona National Natural Park}

\author{
Catalina Gómez-Cubillos ${ }^{1}$, Camila Gómez-Cubillos ${ }^{2}$, Adolfo Sanjuan-Muñoz y Sven Zea ${ }^{1}$ \\ (D) 0000-0003-3384-5969 \\ (iD) $0000-0002-2072-6883$ \\ (D) $0000-0002-4786-862 X$ \\ iD 0000-0002-5657-4877 \\ 1 Universidad Nacional de Colombia - Sede Caribe - Instituto de Estudios en Ciencias del Mar - CECIMAR. Atte. Invemar, Calle 25 No. 2-55, Playa \\ Salguero.Rodadero,Santa Marta,Colombia.macgomezcu@unal.edu.co; szeas@unal.edu.co \\ 2 Pontificia Universidad Javeriana - Departamento de Biología, Facultad de Ciencias, Laboratorio de Ictiología, Unidad de Ecología y Sistemática \\ (UNESIS).Carrera 7 No.40-62,Bogotá D.C.,Colombia.camila_gomezc@hotmail.com \\ 3 Universidad de Bogotá Jorge Tadeo Lozano - Sede Santa Marta, Facultad de Ciencias Naturales e Ingeniería. Carrera 2 No. 11-68, Rodadero, Santa \\ Marta,Colombia.adolfo.sanjuan@utadeo.edu.co
}

\section{RESUMEN}

$\mathrm{E}$ n los arrecifes de coral, la competencia entre organismos bentónicos sésiles por acceso a espacio y otros recursos es determinante en la estructuración de las comunidades. La mortalidad coralina reciente ha favorecido el desarrollo de céspedes algales que pasan a competir con los corales, a menudo desplazándolos, aunque lentamente. Para determinar qué tan frecuentes son las interacciones coral-césped y coralotras categorías bentónicas, y cómo su distribución y resultado (coral gana o coral pierde) son modulados por factores ambientales, se evaluaron fototransectos de banda en 12 estaciones del Parque Nacional Natural Tayrona en Santa Marta, Caribe colombiano. Se encontró que los céspedes algales son el competidor más frecuente de corales masivos así como que la frecuencia de interacciones coral-césped depende de la susceptibilidad particular de una especie de coral a perder tejido y de las perturbaciones que en conjunto afectaron el arrecife donde habita. Además, el resultado de estas interacciones dependió del tipo de organización colonial, siendo las colonias de tipo meandroide y cerioide los competidores más exitosos contra los céspedes, debido al mecanismo de evasión por crecimiento en altura, mientras que las colonias de tipo plocoide fueron más propensas a perder. En general, los factores biológicos (especie de coral y tipo de organización colonial) fueron determinantes en la frecuencia y resultado aparente de las interacciones coral-césped, en tanto que los factores ambientales (gradiente de perturbación, profundidad y grado de exposición al oleaje) parecen no desempeñar un papel preponderante. Por lo tanto, los cambios históricos y futuros en cobertura de cada especie coralina y el tipo de organización colonial en el área de Santa Marta deben reflejar una combinación entre su susceptibilidad a agentes deletéreos y su capacidad de contrarrestar o evadir la competencia, especialmente con céspedes algales.

PALABRAS CLAVE: Competencia, Corales arrecifales, Céspedes algales, Arrecifes de coral, Caribe colombiano.

\section{ABSTRACT}

I n coral reefs, competition between sessile benthic organisms for access to space and other resources is a determining factor in community structuring. Recent coral mortality has favored the development of algal turfs, which are now competing with corals, often displacing them, although slowly. To determine the frequency of interactions between coral-turf and coral-other benthic categories, and how their distribution and results (coral wins or coral loses) are modulated by environmental factors, band photo transects were evaluated for 12 stations in the Parque Nacional Natural Tayrona, Santa Marta, Colombian Caribbean. It was found that algal turfs are the most frequent competitors of massive corals, and that the frequency of coral-turf interactions depends on the particular susceptibility of a coral species to the loss of tissue, and past disturbances that have affected the reef in which it lives. Furthermore, the results of these interactions depend on the ways the colonies are organized, meandroid and cerioid colonies being the most successful in competition against turfs, as their vertical growth constitutes an effective avoidance mechanism. By contrast, plocoid colonies are more prone to lose. In general, biological factors (the coral species in question and type of colonial organization) were determinants in the frequency and apparent result of coral-turf interactions, while environmental factors (disturbance gradient, depth, and degree of wave exposure) appear not to play a predominant role. As a consequence, historical and future changes in coral species cover, and the nature of colony organization in the Santa Marta area, should reflect a combination of their susceptibility to deleterious agents and their capacity to counteract or evade competition, especially with algal turfs.

KEY WORDS: Competition, Reef corals, Algal turfs, Coral reefs, Colombian Caribbean. 


\section{INTRODUCCIÓN}

Los arrecifes de coral son áreas de intensa competencia entre organismos bentónicos sésiles (Barott et al., 2012), por acceso a espacio (establecer, mantener y expandir territorio), luz, alimento, entre otros recursos (Lang y Chornesky, 1990). El resultado de estas interacciones interespecíficas determina en buena medida la estructura de las comunidades coralinas (Fricke et al., 2011; Barott et al., 2012; Gowan et al., 2014).

La competencia entre corales duros y algas bentónicas es frecuente, incluso en arrecifes de coral saludables (Sandin et al., 2008; Harris et al., 2015). Sin embargo, el aumento en la frecuencia e intensidad de perturbaciones, particularmente de origen antropogénico, han desbalanceado los esquemas naturales de estas interacciones, favoreciendo a las algas, especialmente a los céspedes algales.

Los céspedes algales son ensamblajes mixtos de algas con altura de dosel no mayor a $2.0 \mathrm{~cm}$ (Connell et al., 2014), que acumulan sedimentos en sus frondas (Gorgula y Connell, 2004). Tienen el potencial de limitar el asentamiento de larvas de coral (Steneck, 1997; Birrell et al., 2005) y otras algas formadoras de dosel (Kennelly, 1987; Airoldi, 2003). Además, pueden afectar la recuperación del tejido de coral lesionado (Alvarado y Acosta, 2009) y generar la muerte progresiva del tejido coralino adyacente (Jompa y McCook, 2003a, 2003b; Roy, 2004; Harris, 2015), convirtiéndose asî en los principales competidores de los corales hermatípicos (Bruggemann et al., 1994; Ledlie et al., 2007; Barott et al., 2012; Hamilton et al., 2014; Harris, 2015). De hecho, son los promotores de un cambio de fase, en donde los arrecifes dominados por corales pasan a ser dominados por algas, especialmente en ambientes perturbados (Barott et al., 2009, 2012; Haas et al., 2010).

Las interacciones coral-césped ocurren cuando una lesión previa por agentes físicos (tormentas, sedimentación, altas temperaturas, contaminación, entre otros) y/o biológicos (epizootias, depredación, y otros) (Rogers et al., 1982; Bythell et al., 1993; Díaz-Pulido y McCook, 2002; Alvarado y Acosta, 2009), generan mortalidad parcial en las colonias, quedando esqueleto de coral libre de tejido, que es colonizado rápidamente por estos céspedes algales, que una vez establecidos comienzan a interactuar con el tejido vivo de coral en sus fronteras (McManus y Polsenberg, 2004; Fricke et al., 2011; Gowan et al., 2014). Estas interacciones son complejas y variables en el tiempo y el espacio, debido a

\section{INTRODUCTION}

Coral reefs are areas of intense competition between sessile benthic organisms (Barott et al., 2012), for access, among other things, to space (required to establish, maintain and expand territory), light, and food (Lang and Chornesky, 1990). To a large extent the result of these interspecific interactions determines the structure of the coral communities (Fricke et al., 2011; Barott et al., 2012; Gowan et al., 2014).

Competition between hard corals and benthic algae is frequent, even in healthy coral reefs (Sandin et al., 2008; Harris et al., 2015). However, the increased frequency and intensity of disturbances, particularly those of anthropogenic origin, have affected the equilibrium characterizing the natural patterns of these interactions, favoring algae and, in particular, algal turfs.

Algal turfs are mixed assemblages of algae whose canopy does not exceed $2.0 \mathrm{~cm}$ (Connell et al., 2014), and which accumulate sediments in their fronds (Gorgula and Connell, 2004). They have the potential to limit the settlement of coral larvae (Steneck, 1997; Birrell et al., 2005) and other canopy-forming algae (Kennelly, 1987; Airoldi, 2003). They may, in addition, affect the recovery of damaged coral tissue (Alvarado and Acosta, 2009) and lead to progressive die-off of adjacent coral tissue (Jompa and McCook, 2003a, 2003b; Roy, 2004; Harris, 2015). They therefore constitute the principal competitors of hermatypic corals (Bruggemann et al., 1994; Ledlie et al., 2007; Barott et al., 2012; Hamilton et al., 2014; Harris, 2015). In fact, they promote a phase shift, in which reefs previously dominated by corals are taken over by algae, in particular in perturbed environments (Barott et al., 2009, 2012; Haas et al., 2010).

Coral-turf interactions occur when previously existing damage is caused by physical agents (storms, sedimentation, high temperatures, pollution, between others) and/or biological factors (epizootics, depredation, between others) (Rogers et al., 1982; Bythell et al., 1993; DíazPulido and McCook, 2002; Alvarado and Acosta, 2009), generate partial mortality in colonies, stripping tissue from coral skeletons and exposing them to rapid colonization by these algal turfs, which, once established, begin to interact with living coral tissue on the boundary (McManus and Polsenberg, 2004; Fricke et al., 2011; Gowan et al., 2014). These interactions are complex and variable over space and time, as they depend on the species involved, both algae and 
que dependen de las especies que intervienen, tanto de algas como de corales (Titlyanov et al., 2007; Birrell et al., 2008) y del entorno ambiental donde se desarrollan (Vermeij et al., 2010; Barott et al., 2012). Sin embargo, por la dificultad en la identificación de las especies de algas, los céspedes han sido evaluados tradicionalmente de manera generalizada como un único grupo funcional (Connell et al., 2014).

La proliferación de céspedes y de interacciones con corales es evidente especialmente en eventos de gran escala que generan mortalidades masivas, como huracanes, epizootias o blanqueamiento coralino (Rogers et al., 1982; Bythell et al., 1993; Díaz-Pulido y McCook, 2002), pero también ocurre cuando hay mortalidad crónica o episódica de pequeña escala en cada colonia, y pueden pasar desapercibidos en períodos cortos de tiempo (Alvarado y Acosta, 2009). Por su dimensión e implicaciones ambientales, sociales y económicas, es importante cuantificar el daño coralino masivo y crónico y hacer seguimiento de las consecuencias, en las que los céspedes algales pueden jugar un importante papel. No obstante, a nivel mundial pocos estudios han abordado la relación entre el aumento en la cobertura de estos ensamblajes no calcificantes con el cambio climático global (Johnson et al., 2017) y en el Caribe sólo algunos trabajos han relacionado la proliferación de los céspedes a expensas de los constructores de arrecifes como una causa directa de mortalidad de corales pétreos (Roy, 2004; Gómez-Cubillos, 2018). Lo anterior demuestra profundos vacíos de conocimiento en torno al importante papel ecológico que desempeñan los céspedes algales y sus interacciones en los procesos de estructuración de las comunidades de arrecife (Fricke et al., 2011; Barott et al., 2012), y por lo tanto dentro de las posibles trayectorias de recuperación que exhiben los arrecifes perturbados del Caribe colombiano.

Al reconocer la importancia ecológica de las interacciones por espacio en el bentos coralino, y aceptando que los arrecifes están enfrentando escenarios de cambio en diferentes escalas, surge la necesidad de realizar evaluaciones sobre la dinámica espacial de las interacciones coral-césped. En tal sentido, en este estudio se evaluó qué tan frecuentes son las interacciones coralcésped (en relación con otras interacciones), cuál es el resultado aparente de la competencia (coral gana o coral pierde) y cómo algunos factores biológicos y ambientales modulan su frecuencia y resultado. Esto para avanzar en comprender qué tan importantes han sido, son y pueden ser sus efectos en la comunidad coralina. La investigación corals (Titlyanov et al., 2007; Birrell et al., 2008) and the environmental circumstances in which they occur (Vermeij et al., 2010; Barott et al., 2012). However, because of the difficulty of identifying the species of algae involved, turfs have traditionally been evaluated in generalized terms, as a unique functional group (Connell et al., 2014).

The proliferation of turfs and of interactions with corals is particularly evident in large-scale events that cause mass mortality, such as hurricanes, epizootics or coral bleaching (Rogers et al., 1982; Bythell et al., 1993; Díaz-Pulido and McCook, 2002), but it also occurs in the presence of small-scale chronic or episodic mortality in individual colonies, and might not be noticed over short time periods (Alvarado and Acosta, 2009). Because of its scale and its environmental, social and economic implications it is important to quantify mass and chronic damage to corals and to monitor its consequences, processes in which algal turfs can play a major part. However, globally, few studies have examined the relation between these non-calcifying assemblages and global climate change (Johnson et al., 2017), while for the Caribbean only a few works have argued that the proliferation of turfs is detrimental to reefs, as a direct cause of the mortality of hard corals (Roy, 2004; Gómez-Cubillos, 2018). This demonstrates profound gaps in our knowledge concerning the important environmental role played by algal turfs and of their interactions in the processes involved in the structuring of reef communities (Fricke et al., 2011; Barott et al., 2012) and, therefore, in the potential paths towards recovery of the disturbed reefs of the Colombian Caribbean.

Recognition of the ecological importance of competition for space in the coralline benthos and an acceptance that reefs are facing change scenarios of differing scales, leads to a need to evaluate the spatial dynamics of coral-turf interactions. Thus, this study examines the frequency of coral-turf interactions (in relation to other interactions), the apparent results of this competition (coral wins or coral loses), and how certain biological and environmental factors modulate their frequency and their results. The approach represents and attempt to understand how important the effects of these processes have been, are, and might be in the future, for coral communities. The research was carried out in in the Tayrona National Natural Park (Tayrona NNP) in the Colombian Caribbean, an area that is subject to a dramatic alternation between coastal upwelling and continental runoff (Zea, 1993; Bayraktarov, 2013; Bayraktarov et al., 2014a, 2014b), and whose history 
se desarrolló en el Parque Nacional Natural Tayrona -PNN Tayrona- en el Caribe colombiano, área sujeta a una fuerte alternancia climática entre afloramiento costero y descargas continentales (Zea, 1993; Bayraktarov, 2013; Bayraktarov et al., 2014a, 2014b), y cuya historia de perturbación por diversas presiones naturales y antropogénicas, ha generado en las últimas décadas importantes pérdidas de cobertura coralina (ver compilación de Friedlander et al., 2014), y en consecuencia exposición de esqueleto coralino apto para ser colonizado por céspedes.

Esta evaluación espacial a escala de arrecife $(\mathrm{km})$, proporciona una visión instantánea en el tiempo (Barott et al., 2012), convirtiéndose en línea base de referencia que aportará a la comprensión sobre el balance, recuperación y futuro de las comunidades de arrecife del PNN Tayrona.

\section{MATERIALES Y MÉTODOS}

\section{Área de estudio}

En el área de Santa Marta y el Parque Nacional Natural Tayrona (Fig. 1, $11^{\circ} 12^{\prime}-11^{\circ} 22^{\prime} \mathrm{N}$ y $73^{\circ} 57^{\prime}$ $\left.74^{\circ} 15^{\prime} \mathrm{W}\right)$, los arrecifes coralinos que bordean el litoral rocoso son poco amplios, de tipo franjeante, se desarrollan a profundidad media (entre $8-10 \mathrm{~m}$ hasta $20-30 \mathrm{~m}$ ), y están constituidos principalmente por corales masivos hemisféricos. Solamente al interior de las bahías hay arrecifes de parche que alcanzan la superficie (Werding y Sánchez, 1989).

Dada la orientación geográfica de la costa y la dirección de los vientos predominantes (alisios del nororiente), en los costados occidentales de las bahías que están más expuestos al oleaje, la cobertura de corales pétreos con formas de crecimiento costroso es alta, mientras que en los costados orientales que están protegidos abundan las grandes formas masivas y las formaciones coralinas son más complejas y diversas (Werding y Sánchez, 1989; Díaz et al., 2000; Martínez y Acosta, 2005; Vega-Sequeda et al., 2008; Bayraktarov et al., 2014a). No obstante, a pesar de la gran cantidad de fondos duros adecuados para el establecimiento de arrecifes, las formaciones coralinas del área de Santa Marta son poco desarrolladas y su crecimiento es limitado en comparación con otras áreas del Caribe colombiano, debido a la fuerte influencia de un régimen climático bimodal que oscila entre descargas continentales y afloramiento costero (Zea, 1993).

Durante la temporada de lluvias (mayo a noviembre), la temperatura del agua superficial es más cálida $\left(27-29^{\circ} \mathrm{C}\right)$, la of disturbance caused by different natural and anthropogenic pressures have produced significant losses in coral coverage in recent decades (see the compilation of Friedlander et al., 2014) and, as a consequence, the exposure of coral skeletons that are apt for colonization by turfs.

This spatial evaluation, carried out at the scale of the reef $(\mathrm{km})$, provides a snapshot in time (Barott et al., 2012), establishing a baseline that will contribute to an understanding of the balance, recovery and future of the reef communities of the NNP Tayrona.

\section{MATERIALS AND METHODS}

\section{Study area}

In the region of Santa Marta and the PNN Tayrona (Fig. $1,11^{\circ} 12^{\prime}-11^{\circ} 22^{\prime} \mathrm{N}$ and $73^{\circ} 57^{\prime}-74^{\circ} 15^{\prime} \mathrm{W}$ ), the coral reefs that border the rocky coastline are reduced in scale, constituting fringing reefs found at medium depths (between $8-10 \mathrm{~m}$ down to $20-30 \mathrm{~m}$ ), and are principally composed of massive hemispherical corals. Patch reefs that break the surface are found only in the interior of the bays (Werding and Sánchez, 1989).

Given the geographical orientation of the coast and the direction of the prevailing winds (north westerly trade winds), the western shores of the bays are more exposed to wave action, leading to a greater preponderance of crustose hard coral formations, while on the protected eastern sides large massive forms abound and the coral formations are more complex and diverse (Werding and Sánchez, 1989; Díaz et al., 2000; Martínez and Acosta, 2005; Vega-Sequeda et al., 2008; Bayraktarov et al., 2014a). However, despite the large number of solid platforms available for the establishment of reefs, the coral formations in the Santa Marta area are not well developed, their growth being limited in comparison with other parts of Colombian Caribbean, because of the powerful influence of a bimodal climatic regime, which oscillates between periods of continental runoff and coastal upwelling (Zea, 1993).

During the rainy season (May to November) surface water temperatures are high $\left(27-29^{\circ} \mathrm{C}\right)$, salinity declines (34) and the sediment load caused by continental runoff increases water turbidity, while in the dry season (December to April), the coastal upwelling caused by the northeasterly trade winds provokes a fall in sea temperatures (to 20-25 ${ }^{\circ} \mathrm{C}$ ), salinity levels rise (38), along with wave intensity, and in general the waters become clearer (Ramírez, 1983; 
salinidad disminuye (34) y la carga de sedimentos por descargas continentales incrementa la turbidez de las aguas; mientras que en la época seca (diciembre a abril), como resultado del afloramiento costero generado por los vientos alisios del $\mathrm{NE}$, la temperatura del mar desciende $\left(20-25^{\circ} \mathrm{C}\right)$, la salinidad sube (38), aumenta la intensidad del oleaje y en general las aguas son más transparentes (Ramírez, 1983; Zea, 1993; FrancoHerrera, 2005; Vega-Sequeda et al., 2008; Bayraktarov et al., 2014b; Bayraktarov y Wild, 2014). Esta variabilidad climática determina la composición algal, especialmente por una gran proliferación de macroalgas entre enero y abril, que luego disminuyen o desaparecen con el incremento de la temperatura del agua hacia septiembre-noviembre (BulaMeyer, 1990), dejando los sustratos duros no colonizados por macroinvertebrados recubiertos de céspedes algales y algas costrosas coralinas (Díaz-Pulido y Garzón-Ferreira, 2002).
Zea, 1993; Franco-Herrera, 2005; Vega-Sequeda et al., 2008; Bayraktarov et al., 2014b). This climatic variability determines algal composition, generating in particular a great proliferation of macroalgae between January and April, which subsequently declines or disappears with the increase in water temperatures between September and November (Bula-Meyer, 1990), leaving the hard substrates that have not been colonized by macroinvertebrates covered in algal turfs and crustose coralline algae (Díaz-Pulido and Garzón-Ferreira, 2002).

Benthic coverage, the frequency of interactions between hard corals and other benthic categories and the apparent results of coral-turf competition

Field data was gathered in October 2016, during the rainy season, when macroalgal levels were low or nonexistent and algal turfs predominated. In total, 12 stations

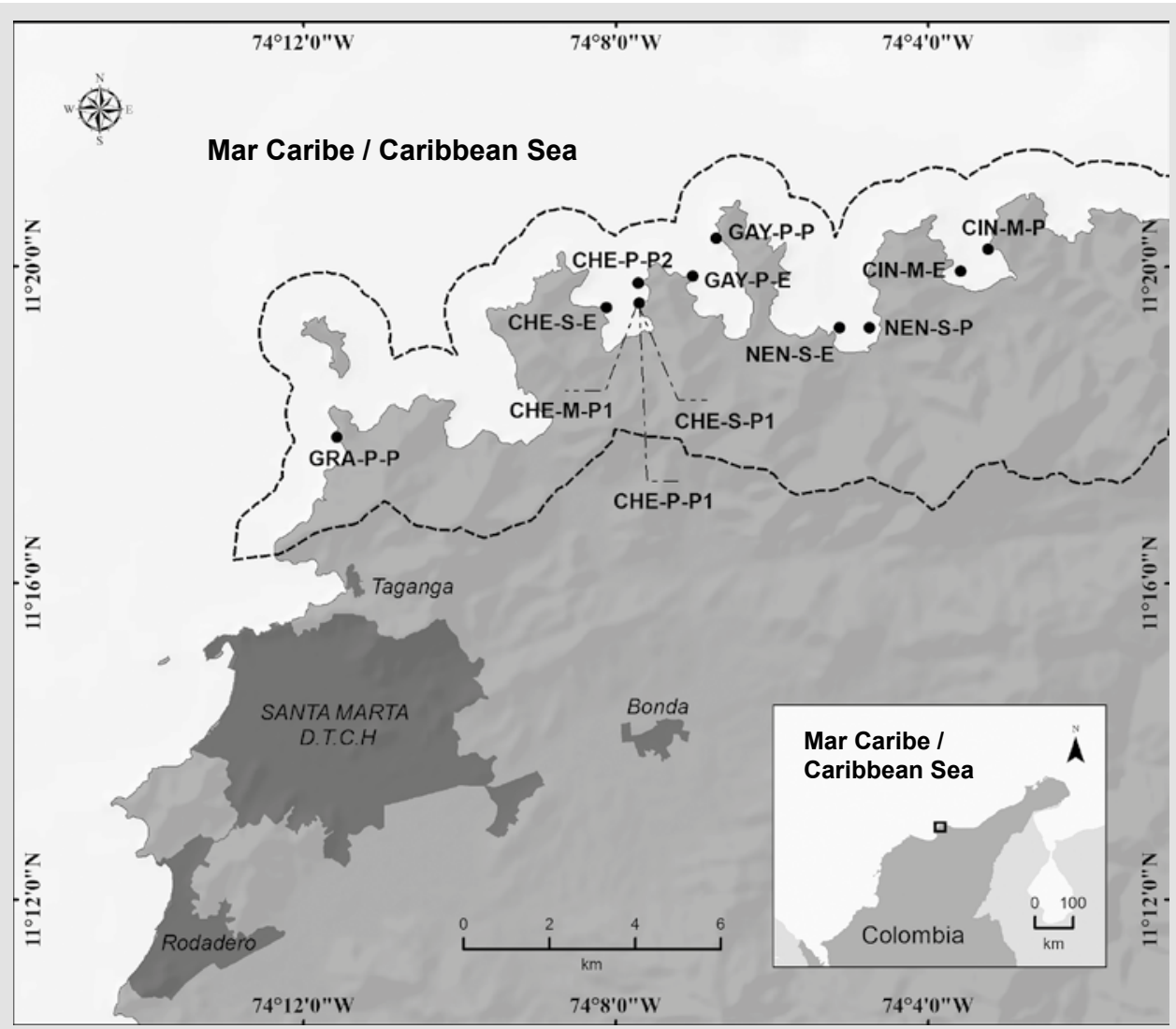

Figura 1. Ubicación de las 12 estaciones de muestreo en el PNN Tayrona, Caribe colombiano. La línea punteada corresponde al polígono que delimita el área protegida. La nomenclatura por estación corresponde a las tres primeras letras del nombre de la bahía (GRA-Granate, CHEChengue, GAY-Gayraca, NEN-Nenguange y CIN-Cinto), la inicial del nivel de profundidad (somero-S, medio-M y profundo-P), y la inicial del nivel de relativo de exposición al oleaje (expuesto-E y protegido-P). Fuente: elaborado por Felipe Valencia, especialista SIG.
Figure 1. Location of the 12 sampling stations in the PNN Tayrona, Colombian Caribbean. The dotted line marks the limits of the protected area. The nomenclature of each station corresponds to the three initial letters of the bay (GRA-Granate, CHE-Chengue, GAY-Gayraca, NEN-Nenguange and CIN-Cinto), a letter denoting depth (shallow-S, medium-M and deep [deep in Spanish]-P), and another the relative level of exposure to wave action (exposed-E and protected-P). Source: prepared by Felipe Valencia, GIS specialist. 
Cobertura bentónica, frecuencia de interacciones entre corales duros con otras categorías bentónicas y resultado aparente de la competencia coral-césped

La información en campo se recolectó en octubre de 2016, durante la temporada de lluvias, con baja o nula presencia de macroalgas y predominio de céspedes algales. En total se evaluaron 12 estaciones (Figura 1), en cinco bahías del PNN Tayrona, comparando el lado protegido (oriental) y expuesto (occidental), en tres niveles de profundidad, si los había, somero (2 a $6 \mathrm{~m}$ ), medio (7 a 12 m) y profundo (> $12 \mathrm{~m})$.

En cada estación, se ubicó un flexómetro sobre el fondo y se evaluaron de dos a cuatro transectos de banda (10 $\mathrm{x} 2 \mathrm{~m}$ ), tomando como referencia los transectos permanentes del Sistema Nacional de Monitoreo de Arrecifes Coralinos de Colombia -SIMAC- (Garzón-Ferreira et al., 2002; Garzón-Ferreira y Rodríguez-Ramírez, 2010).

La composición del bentos se determinó con el método de fotocuadrante (Preskitt et al., 2004). Sobre cada transecto, cada metro y alternando de derecha a izquierda de la cinta se ubicó un cuadrante de PVC de 1" de 50 × 50 $\mathrm{cm}\left(0,25 \mathrm{~m}^{2}\right)$ subdividido en 25 cuadrículas (Gowan et al., 2014), para un total de $2,5 \mathrm{~m}^{2}$ evaluados por transecto. Con una cámara digital Canon Powershot G16 con caja estanca se tomaron fotografías de los cuadrantes completos y de porciones de ellos para lograr mayor detalle.

Las fotografías se procesaron con el programa ImageJ. Por cuadrante se contó el número de cuadrículas, se estimó el área $\left(\mathrm{cm}^{2}\right)$ y midió el perímetro $(\mathrm{cm})$ de las categorías descritas por Caricomp (2001) y Garzón-Ferreira et al. (2002): corales duros (por especie), corales blandos (gorgonáceos y zoantídeos), milepóridos, algas (frondosas, céspedes y costrosas), esponjas (erectas e incrustantes) y sustrato abiótico (arena y escombros). Posteriormente, por cuadrante se calculó la cobertura (\%) por categoría bentónica y especie de coral, a partir de la proporción entre el área ocupada por cada categoría/especie y la sumatoria total de las categorías/especies.

Para estimar en general y por estación la frecuencia (\%) de interacciones coral-césped y coral-otra categoría bentónica, en cada cuadrante se contó el número de interacciones por cuadrícula y se midió el perímetro $(\mathrm{cm})$ de cada interacción. La frecuencia (\%) se calculó a partir de la relación porcentual entre el total de cuadrículas ocupadas por cada tipo de interacción y el total de cuadrículas del cuadrante $(n=25)$. Empleando el mismo método se calculó la frecuencia were evaluated (Figure 1), in five bays of the PNN Tayrona, comparing the protected (eastern) and the exposed (western) sides at three depth levels, if they were to be found: shallow ( 2 to $6 \mathrm{~m}$ ), medium (7 to $12 \mathrm{~m}$ ) and deep (>12 m).

In each station, a flexometer was placed on the floor of the bay, between two and four belt transects $(10 \mathrm{x}$ $2 \mathrm{~m}$ ) being evaluated. The permanent transects developed by the Sistema Nacional de Monitoreo de Arrecifes Coralinos de Colombia (SIMAC) were used for reference purposes (Garzón-Ferreira et al., 2002; Garzón-Ferreira and Rodríguez-Ramírez, 2010).

The composition of the benthos was determined using the photoquadrat method (Preskitt et al., 2004). A $50 \times 50 \mathrm{~cm}\left(0.25 \mathrm{~m}^{2}\right) 1$ " PVC quadrat divided into 25 grid squares was placed at meter intervals, alternating on the right and the left side of the tape (Gowan et al., 2014), resulting in a total of $2.5 \mathrm{~m}^{2}$ being evaluated per transect. Using a Canon Powershot G16 digital camera enclosed in a watertight case, photographs were taken of the whole of the quadrats and of constituent sections, in order to gather more detailed information.

The photographs were processed using the ImageJ program. For each quadrat the number of populated grid squares was counted, covered area estimated (in $\mathrm{cm}^{2}$ ), and the perimeter of each of the categories described by Caricomp (2001) and Garzón-Ferreira et al. (2002) measured $(\mathrm{cm})$, namely: hard corals (by species), soft corals (gorgonacea and zoanthids), milleporidae, algae (fronded, turfs and crustose), sponges (erect and incrussting) and the abiotic substrate (sand and debris). Subsequently, the percentage coverage of each benthic category and coral species was calculated according to the proportion between the area occupied by each category/species and the overall total categories/species.

In order to estimate the frequency (\%) of coral-turf and coral-other-benthic-category interactions both overall and per station, the number of interactions per grid square was counted, and the perimeter of each interaction measured (cm). Frequency (\%) was calculated on the basis of the percentage relation between the total number of grid squares occupied by each kind of interaction and the total number of grid squares in each quadrat $(n=25)$. The same method was used to calculate the frequency (\%) of coral-turf interactions per coral species and type of colony organization, determined by the shape of the corallite and the structure of the corallum (Ogilvie, 1896; Reyes et al., 2010). In order to understand how representative this frequency measure (\%) is compared 
(\%) de interacciones coral-césped por especie de coral y tipo de organización colonial, la cual depende de la forma del coralite y de la estructura del coralum (Ogilvie, 1896; Reyes et al., 2010). Para entender qué tan representativa es esta frecuencia $(\%)$ respecto al total de posibilidades que tiene una especie de coral de interactuar con los céspedes, se calculó un índice de ocurrencia (\%) a partir de la relación porcentual entre el total de cuadrículas de la especie en interacción con céspedes y el total de cuadrículas ocupadas por la especie, y se determinó la relación porcentual entre el perímetro ocupado por la interacción coral-césped de una especie de coral y el perímetro total de la especie (en los cuadrantes).

El resultado aparente de la interacción coralcésped se definió por especie de coral y tipo de organización colonial, a partir de las sugerencias hechas por Barott et al. (2012), Márquez y Zea (2012) y Gowan et al. (2014): a) coral pierde, cuando existen daños visibles en el tejido coralino (cambios de coloración, pérdida de continuidad tegumentaria y necrosis) ocasionados por recubrimiento, sombreado o contacto directo del césped; b) coral gana cuando los pólipos del borde forman elevaciones a manera de labios, faldas o montículos que evaden la interacción, y c) aparentemente neutra cuando el tejido coralino y el césped se encuentran en un mismo nivel (ángulo de $180^{\circ}$ ) y no se observa deterioro de los pólipos en la frontera de interacción. to all the other possible ways a coral species might interact with a turf, an occurrence index (\%) was calculated, based on the percentage relation between the total number of grid squares in which a coral species interacted with turfs and the overall number of grid squares occupied by the same species. In addition, the percentage relation between the perimeter of the area occupied by the coral-turf interaction of a single coral species and the overall perimeter of the species found in the quadrats was calculated.

The apparent result of the coral-turf interaction was determined by examining the different coral species and patterns of colony organization, according to the suggestions made by Barott et al. (2012), Márquez and Zea (2012) and Gowan et al. (2014): a) coral loses when there is visible damage to the coral tissue, (changes to coloration, loss of tegumentary continuity and necrosis) caused by smothering, light deprivation or direct contact with the turf; b) coral wins when the rim polyps form elevations, reminiscent of lips, skirts or mounds that evade interaction, and c) the result is apparently neutral when the coral tissue and the turf meet at the same level (at a $180^{\circ}$ angle) and no deterioration of the polyps is observed at the interaction frontier.

\section{Analysis of the information}

Representativeness using coverage data (\%) for reef-forming species (hard corals and milleporidae) was evaluated by station and by sample (transect) employing

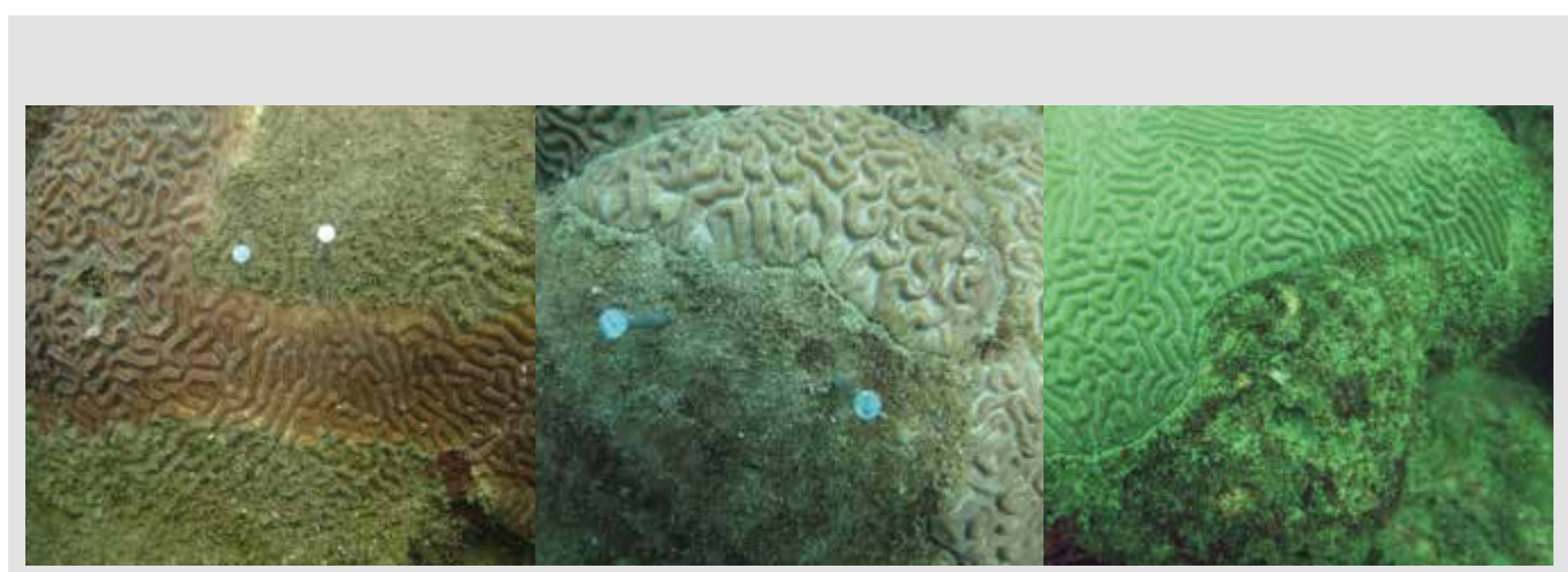

Figura 2. Resultado aparente de interacciones coral-césped, tomando como referencia colonias de Pseudodiploria strigosa: a) coral pierde, b) coral gana y c) interacción aparentemente neutra. Fotos: Sven Zea.
Figure 2. Apparent result of coral-turf interactions, with reference to colonies of Pseudodiploria strigosa: a) coral loses, b) coral wins and c) apparently neutral interaction. Photos: Sven Zea. 
Análisis de la información

La representatividad con los datos de cobertura (\%) de las especies formadoras de arrecife (corales duros y milepóridos) se evaluó por estación y muestra (transecto) mediante diversidad media acumulada de ShannonWiener $\left(\mathrm{H}^{\prime}\right)$ con su respectiva desviación estándar usando el programa EstimateS versión 9.1 (Colwell, 2013) con 1000 permutaciones aleatorias y determinando si la curva alcanzó la asíntota, si el coeficiente de variación de los últimos cinco valores era inferior al $5 \%$ y si la pendiente de la regresión lineal no era significativamente distinta de cero. Con este procedimiento se determinó que en el área de Santa Marta, 3,5 $\mathrm{m}^{2}$ equivalentes a 1,5 transectos, son una muestra representativa de la comunidad bentónica formadora de arrecifes. En consecuencia, para todos los análisis se combinaron todos los transectos de cada estación para obtener un dato por variable por estación.

Las diferencias en la frecuencia de interacciones coral-césped y coral-otras categorías bentónicas entre bahías y estaciones, y el efecto de los factores ambientales (gradiente de perturbación, profundidad de la columna de agua y grado de exposición al viento y oleaje) sobre la frecuencia de estas interacciones, se evaluaron mediante tablas de contingencia y pruebas de independencia de $\mathrm{Chi}^{2}$ a un nivel de confianza de $95 \%$ (Sokal y Rohlf, 1981).

Asumiendo que la cobertura de céspedes algales es mayor en áreas arrecifales perturbadas por actividades humanas (Barott et al., 2012; Harris et al., 2015), se definió un gradiente de perturbación (NE-SW), a partir de la cercanía de la estación al área de desarrollo urbano y portuario de Santa Marta en el lado SW, que se presume disminuye en intensidad y efecto hacia el PNN Tayrona en el NE (Werding y Sánchez, 1988; Zea, 1994; Bayraktarov y Wild, 2014). El análisis del efecto de este factor se realizó sólo para cuatro estaciones con condiciones similares (profundas y protegidas), para evitar que los factores profundidad y exposición enmascararán el efecto del gradiente. Posteriormente, asumiendo que el desarrollo de los céspedes algales es mayor en aguas someras y en sectores protegidos (Fricke et al., 2011), con los datos de las 12 estaciones se evaluó el efecto de la profundidad por niveles (somero, medio y profundo) y por grado de exposición (expuesto y protegido) para cada nivel de profundidad.

Para determinar en general la frecuencia y el resultado (coral gana, coral pierde o aparentemente neutra) de interacciones coral-césped, según la especie de coral y
Shannon-Wiener's index of average accumulated diversity $\left(\mathrm{H}^{\prime}\right)$ applying the appropriate standard deviation, and using the EstimateS program, version 9.1 (Colwell, 2013), with 1,000 random permutations to determine whether the curve reached asymptote, if the variation coefficient of the final five values was below 5\% and if the slope of the linear regression differed significantly from zero. This procedure was used to determine that, in the Santa Marta area, $3.5 \mathrm{~m}^{2}$ - equivalent to 1.5 transects - constitute a representative sample of the benthic reef-forming community. Consequently, for each of the analyses, all the transects in each station were combined in order to obtain a single data point for each variable, at each station.

The differences in the frequency of coral-turf interactions and interactions between coral and other benthic categories between bays and stations, and the effects of environmental factors (perturbation gradient, depth of the water column, and degree of wind-wave exposure) on the frequency of these interactions were evaluated using contingency tables and $\mathrm{Chi}^{2}$ independence test with a confidence level of $95 \%$ (Sokal and Rohlf, 1981).

Assuming that the coverage of algal turfs is greater in reef areas disturbed by human activity (Barott $e t$ al., 2012; Harris et al., 2015), a perturbation gradient was defined (NESW), starting from the station closest to the Santa Marta area of urban and port development in the SW, with the assumption that disturbance effects decrease in intensity and effect towards the PNN Tayrona in the NE (Werding and Sánchez, 1988; Zea, 1994, Bayraktarov and Wild, 2014). The effects of this factor were examined at only four stations, which shared similar characteristics (deep, and protected), in order to prevent depth and exposure factors from masking the effects of the gradient. Subsequently, on the assumption that algal turf development is stronger in shallow waters and in protected zones (Fricke et al., 2011), data from all 12 stations were used to evaluate the effects of depth levels (shallow, medium and deep) and by degree of exposure (exposed and protected) for each depth level.

To determine the overall frequency and results (coral wins, coral loses or apparently neutral) of coral-turf interactions by the coral species involved and the nature of colony organization, only data was analyzed only for the 10 coral species for which more than 30 interactions were registered. The frequency of the interactions was measured using One Way ANOVA, and the results for competition analyzed using $\mathrm{Chi}^{2}$ independence tests (Sokal and Rohlf, 1981).

In order to establish whether coverage (\%) is a covariate of the perimeter occupied by coral-turf 
el tipo de organización colonial, se analizaron solamente los datos de las 10 especies de coral que registraron más de 30 interacciones en total. La frecuencia de interacciones se comparó mediante ANOVA a una vía y los resultados de la competencia con pruebas de independencia $\mathrm{Chi}^{2}$ (Sokal y Rohlf, 1981).

Para determinar si la cobertura (\%) es covariable del perímetro ocupado por interacciones coral-césped (\%), asumiendo a priori que a mayor cobertura de coral mayor es el perímetro de interacción coral-césped, se realizó por separado para cada especie coralina una correlación de Pearson entre el perímetro y la cobertura. Luego, con ANOVA multifactorial (Agresti, 2002) se evaluó si el perímetro por especie de coral varió entre los factores ambientales seleccionados. El perímetro y la cobertura se transformaron con la fórmula de arcoseno (Sokal y Rohlf, 1981) y se probaron los supuestos de normalidad (prueba de Shapiro-Wilk) y homogeneidad de varianzas (prueba de Levene) (Underwood, 1997).

Finalmente, con modelos de regresión binaria (De la Fuente, 2011; Guisande et al., 2013) se evaluó por especie de coral y tipo de organización colonial el efecto de los factores ambientales (gradiente, profundidad y exposición) sobre el resultado de las interacciones coral-césped. Para ello, la variable respuesta (resultado) se transformó a binaria $(0-1)$, siendo cero (0) coral pierde y uno (1) coral no pierde (categoría que incluyó todos los casos en donde el coral ganó o la interacción se mantuvo neutra), y los factores independientes se convirtieron en variables dummy.

\section{RESULTADOS}

Interacciones entre corales y otras categorías bentónicas

En los 70,3 $\mathrm{m}^{2}$ evaluados y las 4053 cuadrículas ocupadas por corales hermatípicos, se identificaron 4010 interacciones entre corales duros con otras categorías bentónicas. Las interacciones coral-césped $(58,7 \%)$ y coralalgas costrosas (13,9 \%) fueron las más frecuentes. El 18,7 $\%$ de las interacciones restantes, se presentó entre corales duros con otros corales, milepóridos, macroalgas frondosas, esponjas y corales blandos, y sólo en el 8,7 \% de los casos el coral no interactuó con otros organismos bentónicos (Figura 3). En virtud de estos resultados, los siguientes análisis se realizaron considerando sólo tres tipos de interacciones: coral-césped, coral-algas costrosas y coral-otras categorías. interactions (\%) - assuming a priori that the greater the coverage of coral, the greater the perimeter of the coral-turf interaction - a separate Pearson correlation was performed for the perimeter and coverage of each coral species. Subsequently, multi-factor ANOVA (Agresti, 2002) was used to evaluate whether the perimeter for each coral species varied according to the selected environmental factors. The perimeter and coverage were transformed using the arcsine formula (Sokal and Rohlf, 1981) and the homogeneity of variances using the Levene test (Underwood, 1997).

Finally, binary regression models (De la Source, 2011; Guisande et al.,2013) were used to evaluate the effects of environmental factors (gradient, depth and exposure) on the results of coral-turf interactions, differentiated by coral species and type of colony organization. For this purpose, the response variable (result) was converted into binary (0$1)$, zero (0) representing coral loses and one (1) coral-doesnot-lose lose (a category that included all the cases in which the coral won or the interaction remained neutral); the independent factors were converted into dummy variables.

\section{RESULTS}

Interactions between corals and other benthic categories

4,010 interactions between hard corals other benthic categories were identified in the $70.3 \mathrm{~m}^{2}$ and the 4,053 grid squares occupied by hermatypic corals. Coralturf $(58.7 \%)$ and coral-crustose algae interactions (13.9\%) were the most frequent. The remaining $18.7 \%$ of interactions occurred between hard corals and other species - namely milleporidae, frondy macroalgae, sponges and soft corals while only $8.7 \%$ of corals had no interaction with any other benthic organisms (Figure 3). These results having been produced, the following analyses were carried out, only three kinds of interaction being examined, namely coralturf, crustose coralline algae and coral-other categories.

The frequency of interactions between corals and other benthic categories varied between bays $\left(\mathrm{Chi}^{2}=191.3\right.$; $\mathrm{P}<0.05 ; \mathrm{GL}=8)$ and between stations $\left(\mathrm{Chi}^{2}=423.1 ; \mathrm{P}<\right.$ $0.05 ; \mathrm{GL}=22$ ). The overall tendency was, except in stations CHE-S-P and GRA-P-P, that coral-turf interactions were the most frequent ( $>56 \%$ ), followed by coral-other categories and crustose coralline algae interactions. In CHE-S-P the dominant interaction was between coral and crusty algae (47.7\%), while in GRA-P-P, although coral-turf interactions dominated, crustose coralline algae interactions were more frequent than 


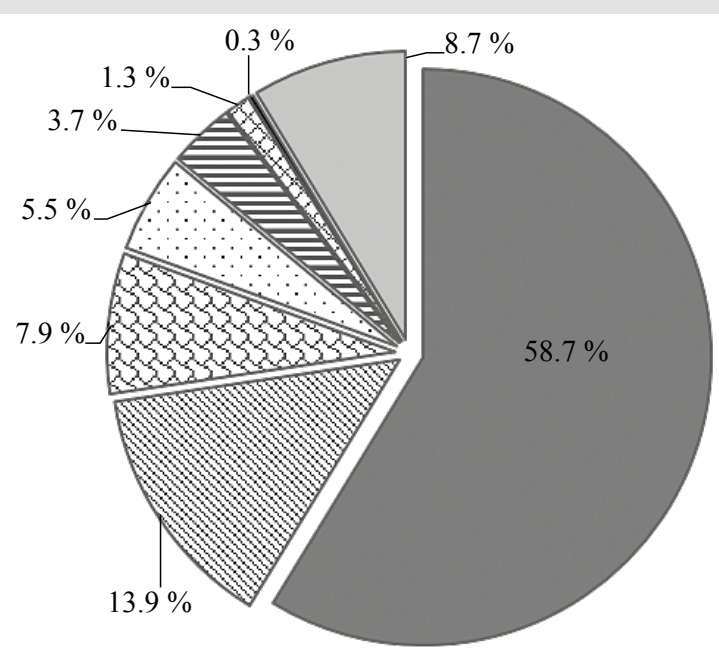

$\square$ Coral-césped / Coral-turf

( Coral-algas costrosas /

Coral-Crustose coralline algae

슬 Coral-coral

$\square$ Coral-milépora /

Coral-milleporidae

- Coral-macroalgas /

Coral-macroalgae

ㄴ. Coral-esponja /

Coral-sponge

- Coral-coral blando /

Coral-soft coral

$\square$ Sin interacción /

No interaction

Figura 3. Frecuencia general de interacciones (\%) entre corales duros con otras categorías bentónicas, en arrecifes del PNN Tayrona.
Figure 3. Overall frequency of interactions (\%) between hard corals and other benthic categories in reefs in the PNN Tayrona.
La frecuencia de interacciones entre corales con otras categorías bentónicas fue diferente entre bahías $\left(\mathrm{Chi}^{2}=191,3 ; \mathrm{P}<0,05 ; \mathrm{GL}=8\right)$ y entre estaciones $\left(\mathrm{Chi}^{2}\right.$ $=423,1 ; \mathrm{P}<0,05 ; \mathrm{GL}=22)$. La tendencia general mostró que la interacción coral-césped fue la más frecuente $(>$ $56 \%$ ), seguida por interacciones coral-otras categorías y coral-algas costrosas, excepto en las estaciones CHE-S-P y GRA-P-P. En CHE-S-P la interacción dominante fue coralalgas costrosas $(47,7 \%)$, mientras que en GRA-P-P aunque dominó la interacción coral-césped, las interacciones coral-algas costrosas fueron más frecuentes que coral-otras categorías bentónicas (Figura 4). those between coral and other benthic categories (Figure 4).

It was also determined that the frequency of interactions depends on the location of the station along the proposed perturbation gradient $\left(\mathrm{Chi}^{2}=25.2 ; \mathrm{P}<0.05 ; \mathrm{GL}\right.$ $=4$ ), coral-turf interactions being most frequent in the reefs that lie closest to Santa Marta Bay (Granate) than in those that are farthest away (Gayraca), while interactions between coral and other benthic categories tend to diminish towards the SW, crustose coralline algae interactions remaining constant ( 15\%) (Figure 5a).

The independence tests showed that the frequency of interactions varies between depth levels $\left(\mathrm{Chi}^{2}=29.3 ; \mathrm{P}<0.05\right.$;

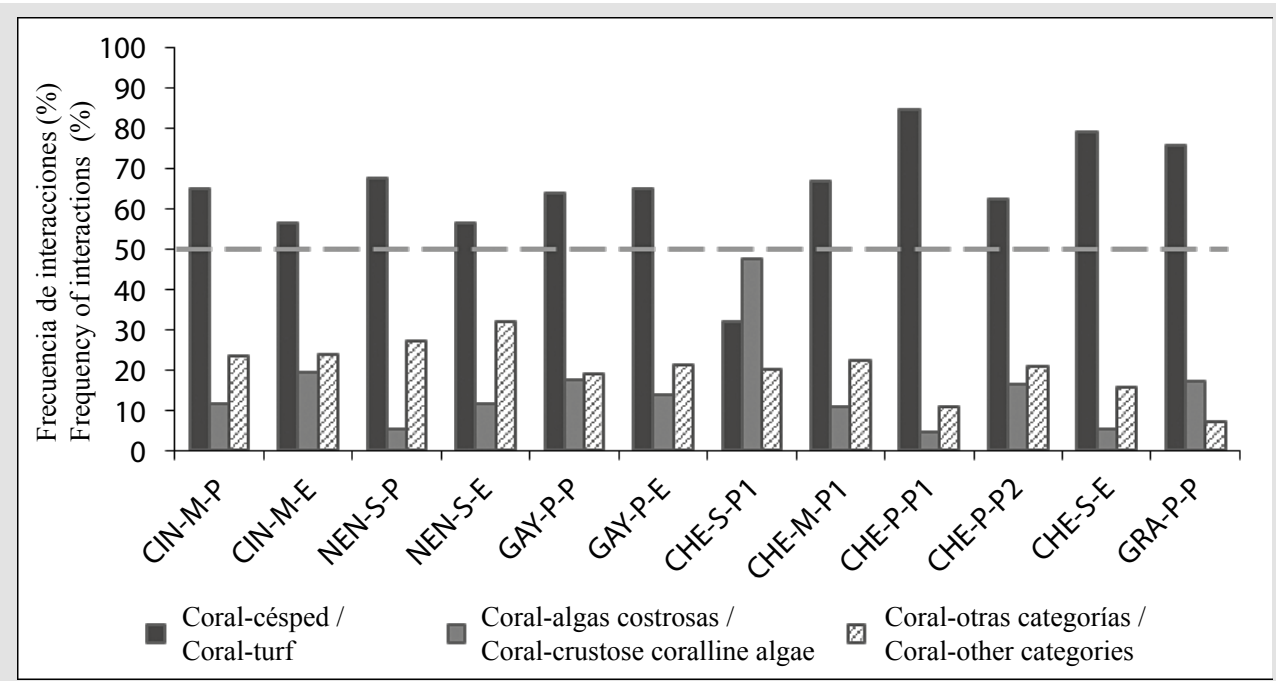

Figura 4. Frecuencia de interacciones (\%) entre corales con otras categorías bentónicas en las 12 estaciones de muestreo del PNN Tayrona. La línea punteada indica el corte de la frecuencia al $50 \%$. Para abreviaturas ver Figura 1.
Figure 4. Frequency of interactions (\%) between corals and other benthic categories in the 12 sample stations of the PNN Tayrona. The dotted line indicates the $50 \%$ cut-off. For abbreviations see Figure 1. 
También se determinó que la frecuencia de interacciones depende de la ubicación de la estación en el gradiente de perturbación propuesto $\left(\mathrm{Chi}^{2}=25,2 ; \mathrm{P}<0,05\right.$; $\mathrm{GL}=4$ ), siendo las interacciones coral-césped más frecuentes en los arrecifes más cercanos a la bahía de Santa Marta (Granate) que en los más lejanos (Gayraca), mientras que las interacciones coral-otras categorías bentónicas tienden a disminuir hacia el SW y las interacciones coral-algas costrosas se mantienen constantes ( 15\%) (Figura 5a).
$\mathrm{GL}=4)$. However, contrary to what was expected, in the PNN Tayrona, coral-turf interactions tend to increase with depth, while coral-other benthic categories and crustose coralline algae interactions were slightly more frequent in shallow environments (Figure $5 b$ ). Individual analyses by depth level showed that in shallow $\left(\mathrm{Chi}^{2}=142.5 ; \mathrm{P}<0.05 ; \mathrm{GL}=2 ; \mathrm{n}=\right.$ 4 ;) and in medium depth stations $\left(\mathrm{Chi}^{2}=54.3 ; \mathrm{P}<0.05\right.$; GL $=2 ; \mathrm{n} .=3$ ), the data and evidence gathered suggest that the frequency of interactions is better explained by the degree

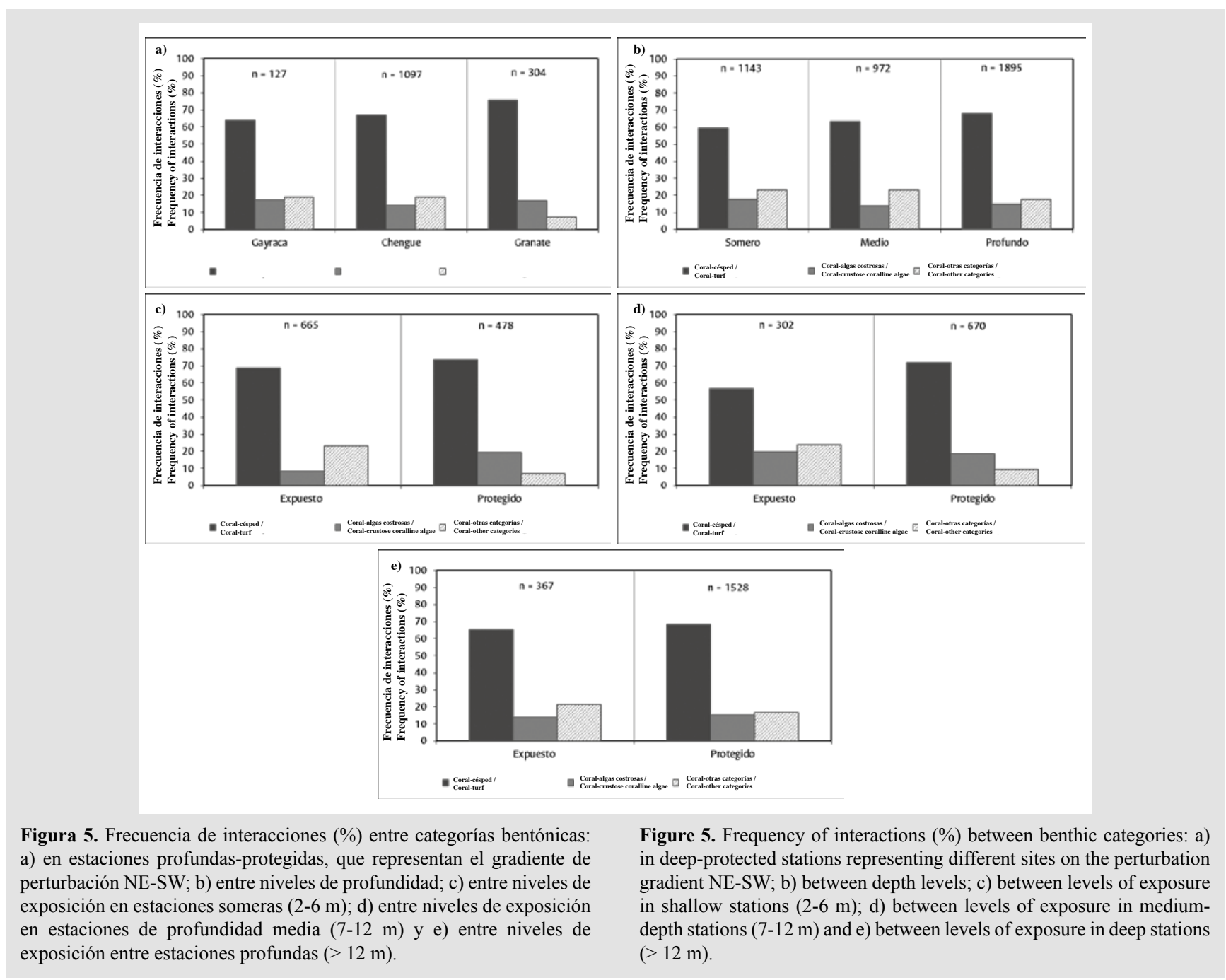

Las pruebas de independencia evidencian que la frecuencia de interacciones varía entre niveles de profundidad $\left(\mathrm{Chi}^{2}=29,3 ; \mathrm{P}<0,05 ; \mathrm{GL}=4\right)$. Sin embargo, opuesto a lo esperado, en el PNN Tayrona, las interacciones coral-césped tienden a aumentar con la profundidad, mientras que las interacciones coral-otras categorías bentónicas y coral-algas costrosas fueron ligeramente más frecuentes en ambientes of exposure to wind and wave action: coral-turf interactions being more frequent, especially in the protected parts of bays, while interactions between coral and other categories increased in exposed areas and crustose coralline algae interactions remained constant $(\sim 19 \%)$, except in shallow, exposed, stations, where their frequency did not exceed $8 \%$ (Figure $5 \mathrm{c}, \mathrm{d})$. By contrast, in the deep stations $\left(\mathrm{Chi}^{2}=4.5 ; \mathrm{P}>0.05\right.$; 
someros (Figura 5b). El análisis individual por nivel de profundidad, mostró que en las estaciones someras $\left(\mathrm{Chi}^{2}=\right.$ $142,5 ; \mathrm{P}<0,05 ; \mathrm{GL}=2 ; \mathrm{n}=4 ;)$ y medias $\left(\mathrm{Chi}^{2}=54,3 ; \mathrm{P}<0,05\right.$; $\mathrm{GL}=2 ; \mathrm{n}=3$ ), la frecuencia de interacciones, según los datos y las pruebas, estuvo mejor explicada por el grado de exposición al viento y el oleaje; siendo en general, las interacciones coral-césped las más frecuentes, particularmente en las áreas protegidas de las bahías, mientras que las interacciones coralotras categorías aumentaron en las áreas expuestas, y las interacciones coral-algas costrosas se mantuvieron constantes ( $19 \%)$, excepto en estaciones someras expuestas, donde su frecuencia no superó $8 \%$ (Figura $5 \mathrm{c}, \mathrm{d}$ ). Por el contrario, en las estaciones profundas $\left(\mathrm{Chi}^{2}=4,5 ; \mathrm{P}>0,05 ; \mathrm{GL}=2 ; \mathrm{n}=\right.$ $5)$, la frecuencia de interacciones no tuvo relación con el nivel de exposición, encontrándose que la proporción entre los tres tipos de interacciones evaluadas es similar tanto en estaciones protegidas como expuestas (Figura 4e).

\section{Interacciones coral-césped}

Las 2578 interacciones coral-céspedes algales identificadas involucraron 16 especies de corales duros. Para las 10 especies de coral seleccionadas con más de 30 interacciones con céspedes, se encontraron diferencias significativas en la frecuencia de interacciones entre especies de coral (ANOVA, $F=4,9 ; P<0,05)$.

Las especies Pseudodiploria strigosa (24,2\%), Colpophyllia natans $(15,9 \%)$ y Montastraea cavernosa $(13,1 \%)$ tuvieron el mayor número de bordes interactuando con céspedes algales, opuesto a lo hallado para Diploria labyrinthiformis $(2,6 \%)$, Orbicella annularis $(1,7 \%)$ y
$\mathrm{GL}=2 ; \mathrm{n}=5$ ), the frequency of interactions was unrelated to the level of exposure, the occurrence of the three types of interaction evaluated being similar in protected and exposed station alike (Figure 5e).

\section{Coral-turf interactions}

The 2578 coral-algal turf interactions identified involved 16 species of hard corals. Significant differences were found in the frequency of interactions between coral species for the 10 species selected that had more than 30 interactions with turfs (ANOVA, $F=4.9 ; P<0.05$ ).

The species Pseudodiploria strigosa (24.2\%), Colpophyllia natans $(15.9 \%)$ and Montastraea cavernosa $(13.1 \%)$ had the highest number of borders interacting with algal turfs, while Diploria labyrinthiformis (2.6\%), Orbicella annularis $(1.7 \%)$ and Meandrina meandrites (1.3\%) had the lowest (Figure 6).

The results of the occurrence index showed that Orbicella franksi $(85.8 \%)$, Porites astreoides (77.5\%) and $M$. cavernosa $(64.2 \%)$ are the species with the highest proportion of grid squares occupied by interactions with algal turfs, while D. labyrinthiformis (38.6\%) and $O$. annularis (44.9\%) have the lowest proportion of living tissues in similar contact (Figure 7a).

According to the perimeter (\%) occupied by coralturf interactions, differentiated by coral species, the results were similar to those of the occurrence index, showing that P. astreoides $(74.3 \%)$ and $O$. franksi $(74.2 \%)$ are the species with the greatest percentage of their perimeters exposed to turfs, while O. annularis (37.5\%) has the lowest (Figure 7b).

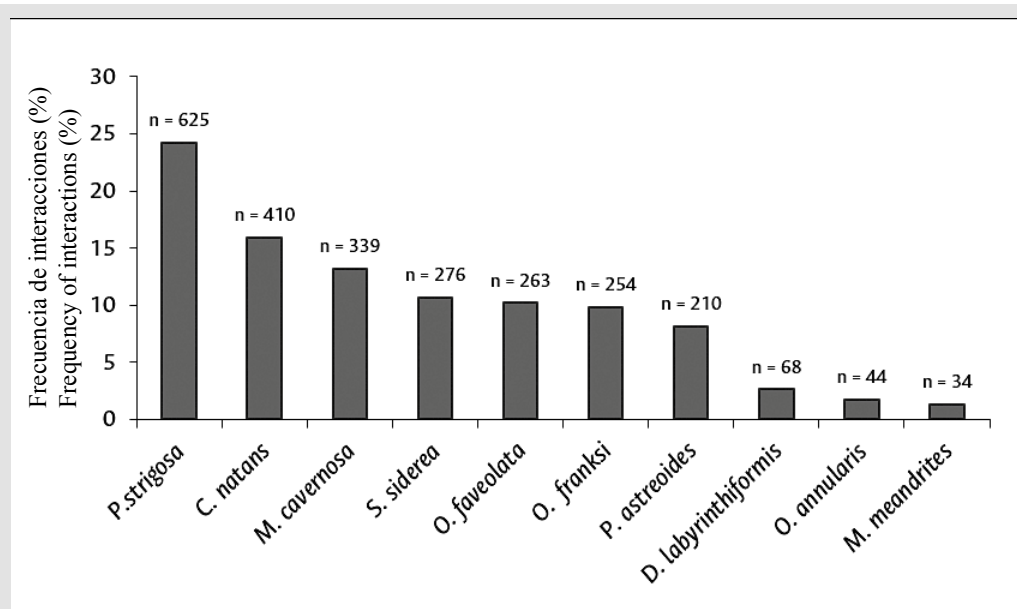

Figura 6. Frecuencia de interacciones (\%) con céspedes, según la especie de coral (relativo al total de interacciones con céspedes).
Figure 6. Frequency of interactions (\%) with turfs, differentiated by coral species (relative to total interactions with turfs). 
Meandrina meandrites (1,3\%) (Figura 6).

Los resultados del índice de ocurrencia mostraron que Orbicella franksi $(85,8 \%)$, Porites astreoides $(77,5 \%)$ y $M$. cavernosa $(64,2 \%)$ son las especies con la mayor proporción de sus cuadrículas ocupadas por interacciones con céspedes algales. Mientras que $D$. labyrinthiformis $(38,6 \%$ ) y $O$. annularis $(44,9 \%)$ son las especies con menor proporción de su tejido vivo en contacto con céspedes algales (Figura 7a).

Según el perímetro $(\%)$ ocupado por interacciones coral-césped por especie de coral, los resultados fueron similares a los del índice de ocurrencia, mostrando que P. astreoides $(74,3 \%)$ y $O$. franksi $(74,2 \%)$ son las especies con mayor porcentaje de su perímetro expuesto a los céspedes; mientras que O. annularis $(37.5 \%)$ tiene
For none of the 10 species evaluated was there a significant correlation between coverage (\%) and perimeter (\%) occupied by coral-turf interactions. This shows that coverage is not a good indicator for predicting the frequency of coral-turf interactions.

The multi-factor ANOVA showed that, of the 10 selected coral species, only in $C$. natans and $P$. astreoides did the perimeter (\%) occupied by coral-turf interactions vary significantly as a result of the selected environmental factors (Table 1). In C. natans the perimeter in interaction with turfs varied with the three factors (gradient, depth and exposure), and there was significant interaction between exposure and gradient: that is, that the differences between gradients varied with exposure. Taken together, these results indicate that for these species the perimeter $(\%)$ of coral-
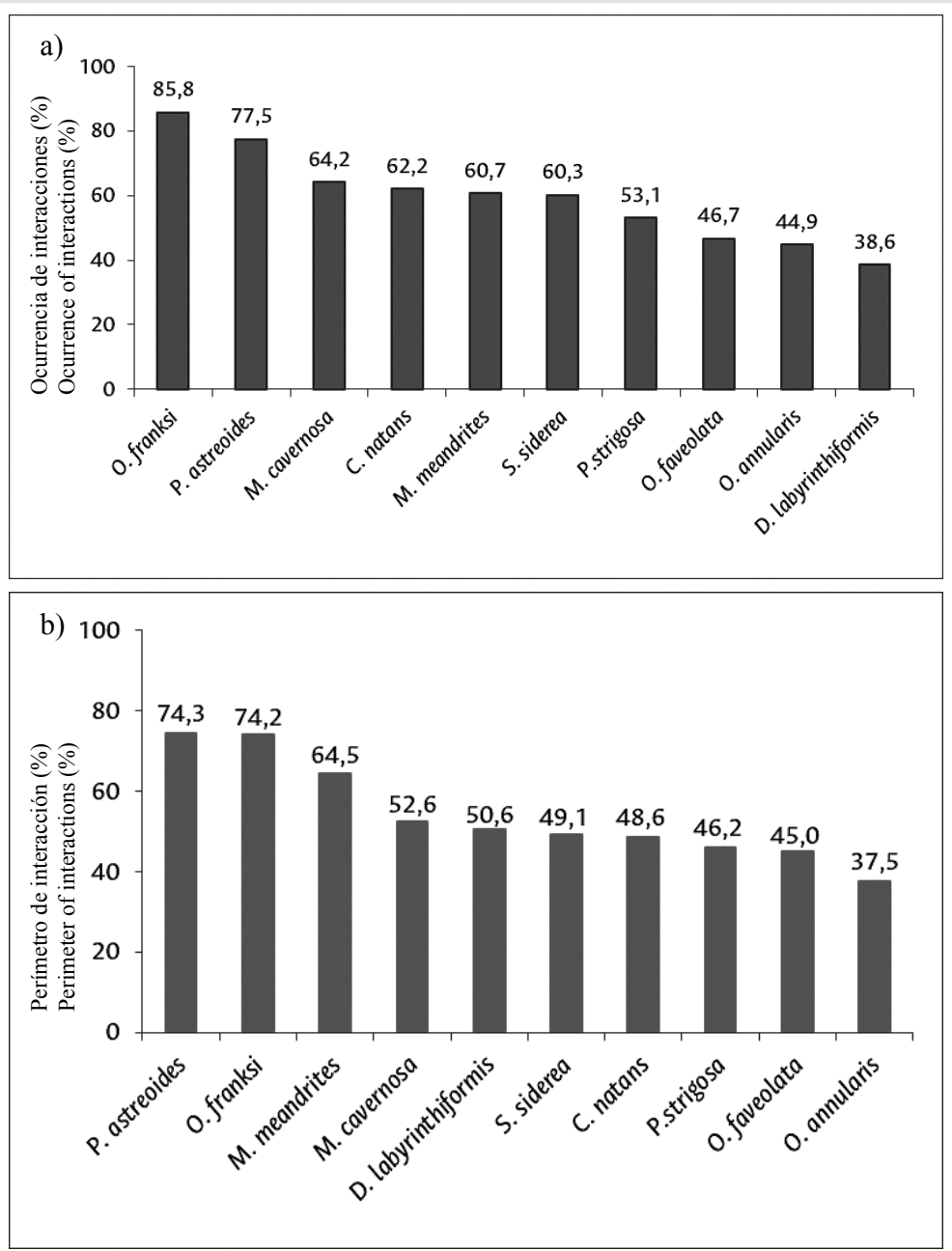

Figura 7. a) Índice de ocurrencia de interacciones (\%) con céspedes algales por especie de coral; b) perímetro ocupado por interacciones (\%) coral-césped.
Figure 7. a) Occurrence index of interactions (\%) with algal turfs, differentiated by coral species; b) perimeter occupied (\%) by coral-turf interactions. 
el menor porcentaje de su perímetro en interacción con céspedes (Figura 7b).

Para ninguna de las 10 especies evaluadas hubo correlación significativa entre la cobertura $(\%)$ y el perímetro (\%) ocupado por interacciones coral-césped. Esto muestra

Tabla 1. Resultados de las correlaciones de Pearson y ANOVA multifactorial para determinar el efecto de variables ambientales y biológicas sobre la frecuencia de interacciones coral-césped por especie de coral. Números en negrita son valores significativos $(\mathrm{P}<0,05)$; guiones $(-)$ son valores no calculados por el modelo estadístico; abreviaturas: Gradiente $(\mathrm{G})$, profundidad (P), Exposición (E). turf interaction was greater in shallow waters with higher levels of anthropogenic influence (Table 2). In the case of $P$. astreoides, although the ANOVA indicates that the perimeter in interaction with turfs varies significantly with depth and gradient, the increase of perimeter with depth was

\begin{tabular}{|c|c|c|c|c|c|c|c|c|c|}
\hline \multirow{3}{*}{$\begin{array}{l}\text { Especie } \\
\text { Specie }\end{array}$} & \multirow{2}{*}{\multicolumn{2}{|c|}{$\begin{array}{c}\text { Correlación } \\
\text { de Pearson } \\
\text { (\% cobertura) } \\
\text { Pearson Correlation } \\
\text { (\% coverage) }\end{array}$}} & \multicolumn{7}{|c|}{$\begin{array}{l}\text { ANOVA multifactorial (\% perímetro) } \\
\text { Multi-factor ANOVA ( } \% \text { perimeter) }\end{array}$} \\
\hline & & & \multicolumn{2}{|c|}{$\begin{array}{l}\text { Gradiente } \\
\text { Gradient } \\
\end{array}$} & \multicolumn{2}{|c|}{$\begin{array}{c}\text { Profundidad (nivel) } \\
\text { Depth (level) } \\
\end{array}$} & \multicolumn{2}{|c|}{$\begin{array}{l}\text { Exposición } \\
\text { Exposure } \\
\end{array}$} & \multirow{2}{*}{$\begin{array}{l}\text { Interacción entre factores } \\
\text { Interaction between factors }\end{array}$} \\
\hline & $\mathbf{r}_{\mathrm{s}}$ & $\mathbf{P}$ & $\mathbf{F}$ & $\mathbf{P}$ & $\mathbf{F}$ & $\mathbf{P}$ & F & $\mathbf{P}$ & \\
\hline \multicolumn{10}{|l|}{ Meandroides / Meandroids } \\
\hline Colpophyllia natans & -0.03 & 0.87 & 5.01 & 0.01 & 4.14 & 0.04 & 7.15 & 0.02 & $E^{*} \mathrm{G}(\mathrm{F}=13.2 ; \mathbf{P}<\mathbf{0 . 0 5})$ \\
\hline Diploria labyrinthiformis & -0.14 & 0.66 & 0.02 & 0.88 & 1.31 & 0.30 & 0.04 & 0.85 & - \\
\hline Meandrina meandrites & -0.14 & 0.64 & 0.91 & 0.50 & 1.22 & 0.37 & 0.28 & 0.62 & - \\
\hline Pseudodiploria strigosa & 0.18 & 0.36 & 0.90 & 0.48 & 4.59 & 0.02 & 3.31 & 0.09 & $\mathrm{E}^{*} \mathrm{G}(\mathrm{F}=0.98 ; \mathrm{P}>0.05)$ \\
\hline \multicolumn{10}{|l|}{ Cerioides / Cerioids } \\
\hline Siderastrea siderea & -0.08 & 0.72 & 2.57 & 0.11 & 1.55 & 0.26 & 0.01 & 0.95 & $\mathrm{E}^{*} \mathrm{G}(\mathrm{F}=6.88 ; \mathrm{P}>0.05)$ \\
\hline Porites astreoides & 0.27 & 0.17 & 4.47 & 0.01 & 4.35 & 0.03 & 3.87 & 0.07 & $\mathrm{E}^{*} \mathrm{G}(\mathrm{F}=0.58 ; \mathrm{P}>0.05)$ \\
\hline \multicolumn{10}{|l|}{ Plocoides / Plocoids } \\
\hline Montastraea cavernosa & 0.05 & 0.82 & 0.16 & 0.96 & 2.10 & 0.16 & 2.98 & 0.11 & $\mathrm{E}^{*} \mathrm{G}(\mathrm{F}=2.95 ; \mathrm{P}>0.05)$ \\
\hline Orbicella faveolata & -0.19 & 0.40 & 0.16 & 0.92 & 0.70 & 0.52 & 1.84 & 0.20 & - \\
\hline Orbicella franksi & 0.29 & 0.36 & 0.70 & 0.54 & 3.17 & 0.12 & 5.34 & 0.06 & - \\
\hline Orbicella annularis & 0.01 & 0.99 & 4.57 & 0.31 & - & - & - & - & - \\
\hline
\end{tabular}

Tabla 2. Promedio y error estándar del perímetro $(\mathrm{m})$ de interacciones coral-césped, por especie de coral, para los factores ambientales: gradiente, profundidad y exposición. Los guiones indican que la especie de coral no estaba presente.
Table 1. Results of the Pearson correlations and multi-factor ANOVA for determining the effect of environmental and biological variables on the frequency of coral-turf interactions, differentiated by coral species. The numbers in bold are significant values $(\mathrm{P}<0.05)$; hyphens $(-)$ are values that have not been calculated by the statistical model. Abbreviations: Gradient (G), Depth (P), Exposure (E).

\begin{tabular}{|c|c|c|c|c|c|c|c|c|c|c|}
\hline \multirow{2}{*}{$\begin{array}{l}\text { Especie } \\
\text { Specie }\end{array}$} & \multicolumn{5}{|c|}{$\begin{array}{l}\text { Gradiente } \\
\text { Gradient }\end{array}$} & \multicolumn{3}{|c|}{$\begin{array}{c}\text { Profundidad } \\
\text { Depth }\end{array}$} & \multicolumn{2}{|c|}{$\begin{array}{l}\text { Exposición } \\
\text { Exposure }\end{array}$} \\
\hline & Cinto & Nenguange & Gay & ce & e & $\begin{array}{l}\text { Somero } \\
\text { Shallow }\end{array}$ & $\begin{array}{c}\text { Medio } \\
\text { Medium }\end{array}$ & $\begin{array}{c}\text { Profundo } \\
\text { Deep }\end{array}$ & $\begin{array}{l}\text { Protegido } \\
\text { Protected }\end{array}$ & $\begin{array}{l}\text { Expuesto } \\
\text { Exposed }\end{array}$ \\
\hline natans & $27 \pm 0.02$ & $0.39 \pm 0.05$ & $0.45 \pm 0.05$ & $0.64 \pm 0.03$ & - & $0.71 \pm 0.05$ & $0.29 \pm 0.02$ & $0.56 \pm 0.04$ & $0.46 \pm 0.03$ & $0.62 \pm 0.05$ \\
\hline D. labyrinthiformis & $0.27 \pm 0.03$ & $1.25 \pm 0.64$ & $0.21 \pm 0.01$ & $0.85 \pm 0.11$ & - & $1.09 \pm 0.31$ & $0.28 \pm 0.03$ & $0.83 \pm 0.14$ & $0.82 \pm 0.13$ & $0.32 \pm 0.05$ \\
\hline M. meandrites & $0.17 \pm 0.06$ & $0.64 \pm 0.17$ & $0.14 \pm 0.04$ & $0.27 \pm 0.08$ & $0.30 \pm 0.09$ & $0.64 \pm 0.17$ & $0.18 \pm 0.04$ & $0.28 \pm 0.07$ & $0.27 \pm 0.05$ & $0.39 \pm 0.17$ \\
\hline strigosa & $0.42 \pm 0.06$ & $0.86 \pm 0.05$ & $0.61 \pm 0.04$ & $0.58 \pm 0.03$ & $0.71 \pm 0.12$ & $0.75 \pm 0.03$ & $0.49 \pm 004$ & $0.61 \pm 0.03$ & $0.58 \pm 0.03$ & $0.69 \pm 0.03$ \\
\hline S. siderea & $0.95 \pm 0.05$ & $0.88 \pm 0.05$ & $0.07 \pm 0.01$ & $0.39 \pm 0.03$ & $0.19 \pm 0.01$ & $0.65 \pm 0.04$ & $0.83 \pm 0.06$ & $0.27 \pm 0.04$ & $0.64 \pm 0.05$ & $0.61 \pm 0.04$ \\
\hline P. as & $.32 \pm 0.05$ & $0.40 \pm 0.07$ & $0.31 \pm 0.05$ & $0.31 \pm 0.02$ & $0.28 \pm 0.06$ & $0.29 \pm 0.02$ & $0.31 \pm 0.03$ & $0.34 \pm 0.02$ & $0.33 \pm 0.02$ & $0.29 \pm 0.02$ \\
\hline M. cavernosa & $0.28 \pm 0.04$ & $0.29 \pm 0.07$ & $0.54 \pm 0.04$ & $0.53 \pm 0.04$ & $0.24 \pm 0.03$ & $0.24 \pm 0.03$ & $0.34 \pm 0.04$ & $0.54 \pm 0.03$ & $0.46 \pm 0.03$ & $0.50 \pm 0.04$ \\
\hline O. faveolata & $0.70 \pm 0.04$ & - & $0.60 \pm 0.17$ & $0.58 \pm 0.04$ & $0.45 \pm 0.09$ & $0.66 \pm 0.09$ & $0.69 \pm 0.05$ & $0.49 \pm 0.05$ & $0.59 \pm 0.04$ & $0.59 \pm 0.06$ \\
\hline O. franksi & - & - & $0.67 \pm 0.08$ & $1.81 \pm 0.16$ & $1.90 \pm 0.13$ & - & $2.06 \pm 0.48$ & $1.63 \pm 0.09$ & $1.73 \pm 0.10$ & 0.99 \\
\hline O. annularis & 4.80 & 0.78 & 0.73 & $0.61 \pm 0.07$ & 0.43 & $0.67 \pm 0.05$ & 4.80 & $0.58 \pm 0.09$ & $0.63 \pm 0.04$ & 4.80 \\
\hline
\end{tabular}


que la cobertura no es un buen indicador para predecir la frecuencia de interacciones coral-césped (Tabla 1).

El ANOVA multifactorial mostró que de las 10 especies de coral seleccionadas, solo en $C$. natans y $P$. astreoides el perímetro (\%) ocupado por interacciones coralcésped varió significativamente con los factores ambientales seleccionados (Tabla 1). En C. natans el perímetro en interacción con céspedes varió con los tres factores (gradiente, profundidad y exposición), y hubo interacción significativa entre la exposición y el gradiente, es decir, que las diferencias en perímetro entre gradientes variaron con la exposición. Estos resultados en conjunto indica que para esta especie el perímetro (\%) de interacción coral-césped fue mayor en aguas someras con mayor influencia antropogénica (Tabla 2). Para el caso de P. astreoides, aunque el ANOVA indica que el perímetro en interacción con céspedes varía significativamente con la profundidad y el gradiente, sólo se observó un ligero aumento del perímetro con la profundidad (Tabla 2). Los resultados de este análisis sugieren que en general los factores ambientales estudiados no son determinantes en la frecuencia de interacciones coral-césped en el área de estudio.

Resultado aparente de la competencia coral-césped

Del total de interacciones coral-césped identificadas $(\mathrm{n}=2578)$, se estableció que en $37,5 \%$ de los casos los corales ganaron, en 30,4\% los corales perdieron y en $32,2 \%$ las interacciones se mantuvieron aparentemente neutras.

Con los datos de las 10 especies de coral seleccionadas $(\mathrm{n}=2523)$, se determinó que el resultado de la interacción varía según la especie de coral $\left(\mathrm{Chi}^{2}=168,7 ; \mathrm{P}<0,05 ; \mathrm{GL}=\right.$ 18). En la Figura 8 se observa que en $D$. labyrinthiformis y $O$. annularis el coral ganó ampliamente. En P. strigosa, C.natans y $P$. astreoides la proporción entre coral gana y neutra fue similar, pero siempre mayor a coral pierde. Para M. meandrites y $O$. faveolata predominaron las interacciones neutras. Por el contrario, en $M$. cavernosa y $O$. franksi el resultado coral pierde fue dominante y para $S$. siderea la proporción entre coral pierde y coral gana fue similar.

Adicionalmente, el resultado de interacciones coral-césped dependió del tipo de organización colonial $\left(\mathrm{Chi}^{2}=55,0 ; \mathrm{P}<0,05 ; \mathrm{GL}=4\right)$. Al combinar todos los datos por tipo colonial (con independencia de la especie), coral gana fue mayor en colonias con formas meandroides y cerioides, aunque en las cerioides el resultado coral only slight (Table 2). The results of this analysis suggest that in general the environmental factors studied are not decisive in explaining the frequency of coral-turf interactions in the area of study.

\section{Apparent results of coral-turf competition}

Of the total number of identified coral-turf interactions $(\mathrm{n}=2578)$, it was established that in $37.5 \%$ of the cases coral won, in $30.4 \%$ it lost and in $32.2 \%$ the interactions remained apparently neutral. The data for the 10 selected coral species $(n .=2523)$ established that the results of the interactions vary according to the coral species in question $\left(\mathrm{Chi}^{2}=168.7 ; \mathrm{P}<0.05 ; \mathrm{GL}=18\right)$. Figure 8 shows that in the case of $D$. labyrinthiformis and $O$. annularis the coral won comprehensively. In the cases of $P$. strigosa, $C$. natans and P. astreoides the proportion of coral wins and neutral results was similar, but always greater than coral loses. For $M$. meandrites and $O$. faveolata neutral interactions predominated, while for $M$. cavernosa and $O$. franksi coral loses predominated and for $S$. siderea the proportion between coral loses and coral wins was similar.

Additionally, the results of coral-turf interactions depended on the nature of colony organization $(\mathrm{Chi} 2=55.0$; $\mathrm{P}<0.05 ; \mathrm{GL}=4)$. When all the data were combined by colony type (independently of species), coral wins were greater in colonies that included meandroid and cerioid forms, although coral loses were more frequent than neutral results, while in meandroid colonies neutral results were greater than coral loses. By contrast, in colonies containing plocoid forms, the coral loses result dominated, followed by neutral, and coral wins (Figure 9).

The binary regression models for the results of the coral-turf interactions $(0=$ coral loses, $1=$ coral-does-notlose), differentiated by kind of colony organization and the selected environmental variables, were statistically significant (meandroids: $\mathrm{Chi}^{2}=11.7 ; \mathrm{P}<0.05$; cerioids: $\mathrm{Chi}^{2}=18.6 ; \mathrm{P}<$ 0.05 and plocoids: $\left.\mathrm{Chi}^{2}=18.1 ; \mathrm{P}<0.05\right)($ Table 3$)$.

In meandroid colonies gradient and exposure were significant $(\mathrm{P}<0.05)$, and their coefficients of correlation (exposure: -0.35 , gradient: -0.15 ) indicate that the possibility of meandroid coral loses increases with less exposure to wave-action and with distance from Santa Marta. For cerioid colonies gradient and depth were significant, and their coefficients (gradient: -0.18 and depth: 0.07 ) indicate that the probability of loss increases the closer they are to Santa Marta and at greater water column depth. In plocoid 


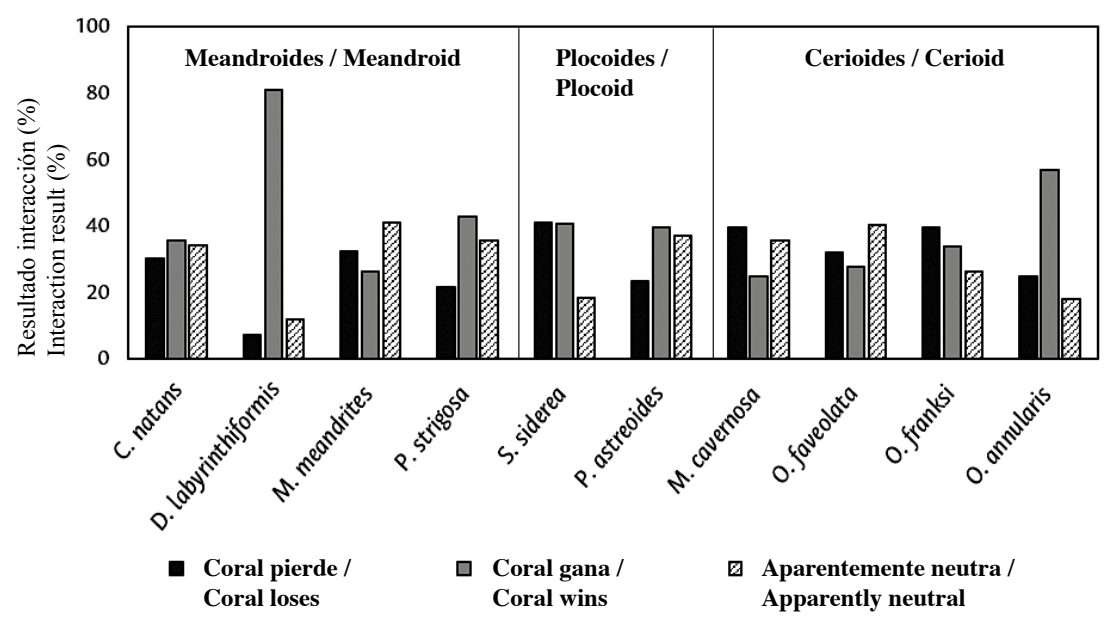

Figura 8. Resultado (\%) de la competencia coral-césped según la especie de coral.

Figure 8. Result (\%) of the coral-turf competition, differentiated by coral species.

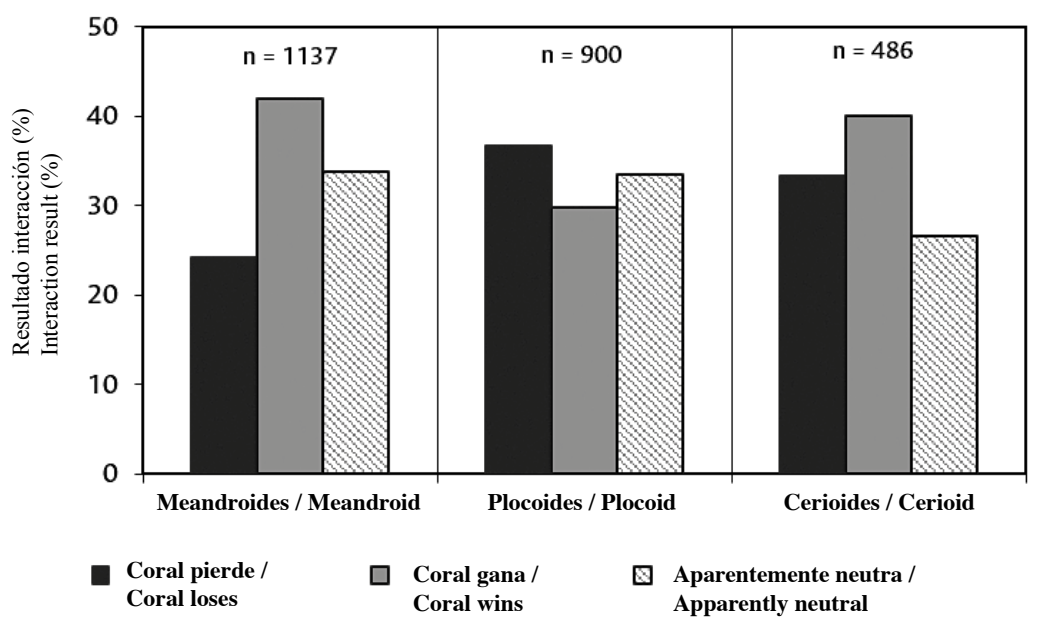

Figura 9. Resultado (\%) aparente de las interacciones coral-césped según el tipo de organización colonial.
Figure 9. Apparent result (\%) of the coral-turf interactions by type of colony organization. pierde fue mayor que el resultado neutro, mientras que en las colonias meandroides el resultado neutro fue mayor que coral pierde. Por el contrario, en colonias con formas plocoides, el resultado coral pierde fue dominante, seguido por el resultado neutro y coral gana (Figura 9).

Los modelos de regresión binaria del resultado de las interacciones coral-césped ( 0 coral pierde, 1 coral no pierde) por tipo de organización colonial y según las variables ambientales seleccionadas, fueron estadísticamente significativos (meandroides: $\mathrm{Chi}^{2}=11,7 ; \mathrm{P}<0,05$; cerioides: $\mathrm{Chi}^{2}=18,6 ; \mathrm{P}<$ 0,05 y plocoides: $\left.\mathrm{Chi}^{2}=18,1 ; \mathrm{P}<0,05\right)($ Tabla 2$)$. colonies only exposure was significant, its coefficient $(-0.94)$ suggesting that the probability of loss increases with less exposure to wave action (Table 3 ).

When this analysis, differentiated by coral species, was conducted it was found that, of the selected species, the models were statistically significant $(\mathrm{P}<0.05)$ for six $(D$. labyrinthiformis, P. strigosa, M. cavernosa, O. faveolata, $O$. franksi and $P$. astreoides), while in the case of $C$. natans, $M$. meandrites, $O$. annularis and $S$. siderea it cannot be said that the result of the competition can be predicted on the basis of the selected variables (Table 3). 
En colonias meandroides el gradiente y la exposición fueron significativos $(\mathrm{P}<0.05)$, y sus coeficientes de correlación (exposición: $-0,35$, gradiente: $-0,15$ ) indican que la posibilidad de que el coral meandroide pierda aumenta con una menor exposición al oleaje y distancia a Santa Marta. Para colonias cerioides el gradiente y la profundidad fueron significativas, y sus coeficientes (gradiente: $-0,18$ y profundidad: 0,07 ) indican que la probabilidad de pérdida aumenta con una menor distancia a Santa Marta y una mayor profundidad de la columna de agua. En colonias plocoides sólo la exposición fue significativa, y su coeficiente $(-0,94)$ sugiere que la probabilidad de pérdida aumenta con una menor exposición al oleaje. (Tabla 3 ).

Al realizar este análisis por especie de coral, se encontró que de las 10 especies seleccionadas, en seis de ellas (D. labyrinthiformis, P. strigosa, M. cavernosa, $O$. faveolata, $O$. franksi y $P$. astreoides) los modelos fueron estadísticamente significativos $(\mathrm{P}<0,05)$, mientras que en $C$.natans, $M$. meandrites, $O$. annularis y $S$. siderea el resultado de la competencia no se puede predecir a partir de las variables seleccionadas (Tabla 3 ).

La profundidad fue la variable más importante para $P$. strigosa, $O$. franksi y $P$. astreoides, y sus coeficientes $(0,06,0,22$ y 0,14 , respectivamente) indican que a mayor profundidad aumenta la probabilidad de pérdida para estas especies. El gradiente de perturbación fue la variable más importante para $O$. faveolata y aportó al modelo de $P$. astreoides, y sus coeficientes $(-0,32$ y $-4,29$, respectivamente) señalan que a menor distancia de Santa Marta mayor es la probabilidad de pérdida. La exposición al oleaje aportó a los modelos de $O$. faveolata y $P$. strigosa, y sus coeficientes $(-2,41$ y $-5,75$, respectivamente) sugieren que a menor exposición aumenta la probabilidad de pérdida. Para $D$. labyrinthiformis y M. cavernosa, aunque el modelo fue significativo, ninguna variable pudo explicar el resultado de la competencia (Tabla 3 ).

Empero para este análisis el $\mathrm{R}^{2}$ de Nagelkerke no superó $27 \%$ en ninguno de los 13 casos evaluados, y el cociente entre la probabilidad de que ocurra el suceso que define la variable dependiente, frente a la probabilidad de que no ocurra en presencia o ausencia del factor, en todos los casos fue menor a $3 \%$. Por lo tanto, estos modelos, aunque fueron estadísticamente significativos, sólo explican un bajo porcentaje de la varianza de la variable dependiente (coral pierde y coral no pierde), por lo que
Depth was the most important variable in the case of $P$. strigosa, $O$. franksi and $P$. astreoides, whose coefficients $(0.06,0.22$ and 0.14 , respectively) indicate that at greater depth there is an increased possibility that the species will lose. The perturbation gradient was the most important variable for $O$. faveolata and contributed to the model for $P$. astreoides, and its coefficients ( -0.32 and -4.29 , respectively) indicate that the probability of loss is greater at less distance from Santa Marta. Exposure to wave action contributed to the models for $O$. faveolata and P. strigosa, and their coefficients (-2.41 and -5.75 , respectively) suggest that less exposure increases the probability of loss. In the case of D. labyrinthiformis and $M$. cavernosa, although the model was significant, no variable was capable of explaining the result of the competition (Table 3).

However, for this analysis, in none of the 13 cases evaluated did Nagelkerke's $\mathrm{R}^{2}$ exceed $27 \%$, and the quotient between the probability that the event defining the dependent variable and the probability that it does not occur in the presence or absence of the factor, was in every case below $3 \%$. Therefore, these models, though statistically significant, only explain a small percentage of the variance of the dependent variable (coral loses and coral-does-not-lose), for which reason it is assumed that the selected factors are not good predictors of the results of coral-turf competition.

\section{DISCUSSION}

Interactions between corals and other benthic categories

In the reefs found in the PNN Tayrona, hermatypic corals interact with algae (turfs, macroalgae and crustose coralline species), others (massive, Milleporidae and soft corals) and sponges, the most frequent interactions being between coral-algal turf and crustose coralline algae (58.7 $\%$ and $13.9 \%$ respectively).

In order to interpret these results correctly it should be borne in mind that coral-turf interactions generally occur when physical and/or biological agents produce a prior lesion in the coral tissue, which caused partial mortality in the colonies (Rogers et al., 1982; Bythell et al., 1993; Díaz-Pulido and McCook, 2002; Alvarado and Acosta, 2009), leaving behind the exposed skeleton, which is then colonized by turfs (McManus and Polsenberg, 2004; Fricke et al., 2011; Gowan et al., 2014). Therefore, the fact that coral-turf interactions are the most frequent reflects the residual effect of the perturbation gradient to which the reefs have been exposed (Hughes and Connell 1999). This 
Tabla 3. Regresión logística binaria para predecir el resultado de la competencia coral-césped (coral pierde y coral no pierde) por tipo de organización colonial y especie de coral, en función a los factores gradiente, profundidad y exposición al oleaje. Números en negrita son valores significativos $(P<0,05) ; \mathrm{R}^{2}=$ porcentaje de datos clasificados en el modelo; $\mathrm{Chi}^{2}$ de la prueba de independencia entre los coeficientes de verosimilitud del modelo; $\mathrm{Chi}_{\mathrm{w}}{ }^{2}$ de Wald para pruebas multivariadas; $\mathrm{B}=$ coeficiente de correlación en el modelo.
Table 3. Binary logistic regression to predict the result of coral-turf competition (coral loses and coral-does-not-lose) for type of colony organization and coral species, in function of the factors gradient, depth and exposure to wave action. The numbers in bold are significant values $(\mathrm{P}<0.05) ; \mathrm{R}^{2}=$ percentage of data classified in the model; $\mathrm{Chi}^{2}$ test of independence of the accuracy of the model; de Wald $\mathrm{Chi}_{\mathrm{w}}{ }^{2}$ for multivariate samples; B = correlation coefficient for the model.

\begin{tabular}{|c|c|c|c|c|c|c|c|c|c|c|c|c|}
\hline \multirow{2}{*}{$\begin{array}{l}\text { Tipo colonial / } \\
\text { especie de coral } \\
\text { Colony type / coral } \\
\text { species }\end{array}$} & \multicolumn{3}{|c|}{$\begin{array}{l}\text { Modelo } \\
\text { Model }\end{array}$} & \multicolumn{3}{|c|}{$\begin{array}{l}\text { Gradiente } \\
\text { Gradient }\end{array}$} & \multicolumn{3}{|c|}{$\begin{array}{c}\text { Profundidad } \\
\text { Depth }\end{array}$} & \multicolumn{3}{|c|}{$\begin{array}{l}\text { Exposición } \\
\text { Exposure } \\
\end{array}$} \\
\hline & $\mathbf{P}$ & $\mathrm{Chi}^{2}$ & $\mathbf{R}^{2}$ & $\mathbf{P}$ & $\mathrm{Chi}_{\mathrm{w}}{ }^{2}$ & B & $\mathbf{P}$ & $\mathrm{Chi}_{\mathrm{w}}{ }^{2}$ & B & $\mathbf{P}$ & $\mathrm{Chi}_{w}{ }^{2}$ & B \\
\hline $\begin{array}{l}\text { Meandroides / } \\
\text { Meandroids }\end{array}$ & 0.008 & 11.7 & 75.8 & 0.029 & 4.8 & -0.15 & 0.239 & 1.4 & 0.026 & 0.028 & 4.8 & -0.35 \\
\hline C.natans & 0.076 & 6.9 & 69.8 & 0.013 & 6.2 & -0.27 & 0.370 & 0.8 & -0.31 & 0.668 & 0.2 & -0.11 \\
\hline D. labyrinthiformis & 0.001 & 35.7 & 100.0 & 0.994 & 0.0 & -40.0 & 0.992 & 0.0 & -21.5 & 0.994 & 0.0 & -58.7 \\
\hline M. meandrites & 0.098 & 6.3 & 76.5 & 0.150 & 2.1 & 0.99 & 0.050 & 3.8 & 0.40 & 0.243 & 0.9 & 1.27 \\
\hline P. strigosa & 0.004 & 13.4 & 78.4 & 0.167 & 1.9 & -1.15 & 0.050 & 3.8 & 0.065 & 0.012 & 6.3 & -5.75 \\
\hline Cerioides / Cerioids & 0.001 & 18.6 & 66.9 & 0.026 & 5.0 & -0.18 & 0.035 & 4.5 & 0.07 & 0.984 & 0.0 & -0.004 \\
\hline S. siderea & 0.256 & 4.0 & 58.0 & 0.348 & 0.9 & 0.11 & 0.262 & 1.2 & -0.05 & 0.078 & 3.1 & 0.52 \\
\hline P. astreoides & 0.001 & 26.1 & 73.7 & 0.005 & 7.8 & -4.29 & 0.034 & 4.5 & 0.14 & 0.383 & 0.8 & -3.9 \\
\hline Plocoides / Plocoids & 0.001 & 18.1 & 63.3 & 0.075 & 3.2 & -0.15 & 0.564 & 0.3 & -0.02 & 0.001 & 16.8 & -0.94 \\
\hline S. siderea & 0.256 & 4.0 & 58.0 & 0.348 & 0.9 & 0.11 & 0.262 & 1.2 & -0.05 & 0.078 & 3.1 & 0.52 \\
\hline P. astreoides & 0.001 & 26.1 & 73.7 & 0.005 & 7.8 & -4.29 & 0.034 & 4.5 & 0.14 & 0.383 & 0.8 & -3.9 \\
\hline Plocoides / Plocoids & 0.001 & 18.1 & 63.3 & 0.075 & 3.2 & -0.15 & 0.564 & 0.3 & -0.02 & 0.001 & 16.8 & -0.94 \\
\hline M. cavernosa & 0.040 & 8.3 & 61.1 & 0.439 & 0.6 & -0.13 & 0.203 & 1.6 & 0.70 & 0.064 & 3.4 & -0.56 \\
\hline O. faveolata & 0.001 & 22.7 & 70.0 & 0.013 & 6.2 & -0.32 & 0.476 & 0.5 & -0.05 & 0.001 & 13.5 & -2.41 \\
\hline O. franksi & 0.050 & 7.6 & 63.0 & 0.857 & 0.03 & -0.45 & 0.023 & 5.2 & 0.22 & 0.314 & 1.0 & -0.77 \\
\hline O. annularis & 0.489 & 2.4 & 79.5 & 0.319 & 1.0 & -0.64 & 0.519 & 0.2 & 0.10 & 0.212 & 1.9 & -2.40 \\
\hline
\end{tabular}

se asume que los factores seleccionados no son buenos predictores del resultado de la competencia coral-césped.

\section{DISCUSIÓN}

Interacciones entre corales y otras categorías bentónicas

En los arrecifes del PNN Tayrona, los corales hermatípicos interactúan con algas (céspedes, macroalgas y costrosas incrustantes), otros corales (masivos, milepóridos y blandos) y esponjas, siendo las interacciones coral-céspedes algales $(58,7 \%)$ y coral-algas costrosas $(13,9 \%)$ las más frecuentes.

Para interpretar estos resultados, se debe tener en cuenta que las interacciones coral-césped generalmente ocurren cuando agentes físicos y/o biológicos producen history includes events such as the mass mortality of the sea urchin Diadema antillarum in the 1980s (Lessios et al., 1984), mass bleaching events in 1987, 1995, 2005 and 2010 (Navas-Camacho et al., 2010), hurricanes (Johan in 1988, Lenny in 1999 and Matthew in 2016, immediately before the fieldwork for this study was carried out), coral diseases such as white band in Acropora spp. (Gladfelter, 1982; Aronson and Precht, 2011) and aspergillosis in Gorgonia spp. between 1985 and 1988 (Garzón-Ferreira and Zea, 1992), the impact of invasive species such as Pterois volitans (Acero et al., 2019), and overfishing (Friedlander et al., 2014). These disturbances have led to algal turfs currently being the principal competitors of hard corals in the PNN Tayrona, a trend that has been reported previously for other tropical reefs (Hughes, 1994; Díaz-Pulido and McCook, 2002; Littler et al., 2006; Hughes et al., 2007; 
una lesión previa en el tejido coralino que causa mortalidad parcial en las colonias (Rogers et al., 1982; Bythell et al., 1993; Díaz-Pulido y McCook, 2002; Alvarado y Acosta, 2009), quedando esqueleto expuesto que es colonizado por los céspedes (McManus y Polsenberg, 2004; Fricke et al., 2011; Gowan et al., 2014). Por lo tanto, el hecho de que las interacciones-coral-césped sean las más frecuentes, refleja el efecto residual de la trayectoria de perturbación a la que han estado expuestos estos arrecifes (Hughes y Connell, 1999). Esta historia incluye acontecimientos como la mortalidad masiva del erizo Diadema antillarum en la década de los años 80 del siglo pasado (Lessios et al., 1984), blanqueamientos masivos en 1987, 1995, 2005 y 2010 (Navas-Camacho et al., 2010), huracanes (Johan en 1988, Lenny en 1999, Mathew en 2016, inmediatamente antes de este estudio), enfermedades coralinas como banda blanca en Acropora spp. (Gladfelter, 1982; Aronson y Precht, 2011) y aspergilosis en Gorgonia spp. entre 1985 y 1988) (Garzón-Ferreira y Zea, 1992), impactos por especies invasoras como Pterois volitans (Acero et al., 2019) y sobrepesca (Friedlander et al., 2014). Estas perturbaciones han provocado que los céspedes algales actualmente sean los principales competidores de corales duros en el PNN Tayrona, tendencia ya registrada para otros arrecifes tropicales (Hughes, 1994; Díaz-Pulido y McCook, 2002; Littler et al., 2006; Hughes et al., 2007; Sandin et al., 2008; Fricke et al., 2011; Barott et al., 2012; Harris et al., 2015).

Por su parte, la baja frecuencia de interacciones coral-algas costrosas, algas importantes para la calcificación y construcción arrecifal (Heyward y Negri, 1999; Vermeij et al., 2010; Gómez-Lemos y Díaz-Pulido, 2017), puede obedecer al efecto derivado de la acción sinérgica de perturbaciones a escala global como la acidificación de los océanos (Cyronaka y Eyrea, 2016) y a escala local como la disminución en las poblaciones de herbívoros (Burkepile y Hay, 2010), factores que limitan la formación de algas costrosas, y por ende su probabilidad de interactuar con otros organismos bentónicos.

Aunque en los arrecifes del PNN Tayrona las interacciones coral-césped son las más frecuentes, se encontraron diferencias en la frecuencia de estas interacciones entre bahías y estaciones. Por ejemplo, en CHE-S-P la interacción coral-algas costrosas fue dominante $(47,7 \%)$, tal vez porque esta estación está conformada principalmente por grandes cabezas de corales masivos con pocas áreas muertas, hecho que sugiere que el nivel de impacto de las perturbaciones afecta de manera diferencial
Sandin et al., 2008; Fricke et al., 2011; Barott et al., 2012; Harris et al., 2015).

For its part, the low frequency of interactions between coral and crusty algae, species that are important to the building and calcification of reefs (Heyward and Negri, 1999; Vermeij et al., 2010; Gómez-Lemos and Díaz-Pulido, 2017), might respond to effects derived from the synergistic action of global perturbations, such as the acidification of the oceans (Cyronaka and Eyrea, 2016) and at local level to factors such as the diminution in the population of herbivores (Burkepile and Hay, 2010), factors that limit the formation of crusty algae and, in consequence, the probability that they will interact with other benthic organisms.

Although coral-turf interactions are the most common kinds of interaction in the Tayrona National Natural Park, differences were found in their frequency between bays and stations. For example, in CHE-S-P the crustose coralline algae interaction dominated (47.7\%), perhaps because this station is made up principally of large heads of massive corals with few dead areas, a fact that suggests the level of impact exerted by perturbation affects each reef differentially, according to the intensity, periodicity and proximity of the event in question (Sousa, 1979; Connell, 1997).

Given that the environmental context plays a decisive role in the dynamics of interactions in the benthos (Airoldi et al., 1995; Burkepile and Hay, 2010; Vermeij et al., 2010; Barott et al., 2012; Swierts and Vermeij, 2016), in this research it was found that coral-turf interactions tend to be more frequent in reefs that are closer to Santa Marta, an area of urban and port development, while along the SW-NE axis that leads away from Santa Marta, interactions between coral and other benthic categories diminish. This suggests the existence of a major anthropogenic perturbation affecting corals (Zea, 1994), caused by a reduced population of herbivores, and increased levels of nutrients and sediments in the water (Gorgula and Connell, 2004; Barott et al., 2012), conditions that are prejudicial to coral species and increase the loss of reef calcifiers (Díaz-Pulido and McCook, 2002; Barott et al., 2012; Bender-Champ et al., 2014), but that are beneficial to the algal turfs, which are able to take advantage of the situation.

On the matter of depth, Fricke et al. (2011) demonstrate experimentally that, in reefs in Curaçao, algal turfs are more abundant in shallow waters. However, in this research the frequency of coral-turf interactions increased with depth while coral-other categories interactions 
cada arrecife, según sea la intensidad, periodicidad y cercanía del evento (Sousa, 1979; Connell, 1997).

Dado que el contexto ambiental juega un papel determinante en la dinámica de las interacciones en el bentos (Airoldi et al., 1995; Burkepile y Hay, 2010; Vermeij et al., 2010; Barott et al., 2012; Swierts y Vermeij, 2016), en esta investigación se encontró que las interacciones coralcésped tienden a ser más frecuentes en arrecifes cercanos a la ciudad de Santa Marta, área de desarrollo urbano y portuario; mientras que en esta misma dirección SW-NE, las interacciones coral-otras categorías bentónicas disminuyen. Lo anterior sugiere una mayor perturbación antropogénica sobre los corales (Zea, 1994), dada por la reducción en las poblaciones de herbívoros e incremento de nutrientes y sedimentos (Gorgula y Connell, 2004; Barott et al., 2012), condiciones que son perjudiciales para los corales e incrementan la pérdida de los organismos calcificadores del arrecife (Díaz-Pulido y McCook, 2002; Barott et al., 2012; Bender-Champ et al., 2014), pero que son ventajosas para los céspedes algales.

Respecto a la profundidad, Fricke et al. (2011) demostraron experimentalmente que, en arrecifes de Curaçao, los céspedes algales son más abundantes en aguas someras. No obstante, en este estudio la frecuencia de interacciones coral-césped aumentó con la profundidad y las interacciones coral-otras categorías disminuyeron, indicando que a profundidades de hasta $15 \mathrm{~m}$ la luz no es un factor limitante para el desarrollo de ensamblajes de céspedes algales, aunque la composición de los ensamblajes sí varía (Gómez-Cubillos, 2018). Además, la mortalidad parcial de tejido coralino en el PNN Tayrona ha sido mayor en aguas más profundas (> $12 \mathrm{~m})$, particularmente durante eventos de blanqueamiento y por epizootias (Acosta et al., 2018), y la acumulación de sedimentos por resuspensión aumenta con la profundidad (Bayraktarov, 2013; Bayraktarov et al., 2014a), permitiendo su mayor acumulación en las frondas de los céspedes, y por lo tanto incrementando el efecto lesivo de estos ensamblajes en contacto con el tejido coralino.

Para el factor exposición al oleaje, se encontró que las interacciones coral-césped son más frecuentes en áreas protegidas con profundidades menores a $12 \mathrm{~m}$, mientras que, en áreas expuestas, aunque también dominaron las interacciones coral-césped, aumentó la proporción de interacciones coral-otras categorías. Por el contrario, en aguas profundas $(>12 \mathrm{~m})$ no se encontraron diferencias en la frecuencia de interacciones entre áreas expuestas y protegidas. Estos resultados sugieren que en áreas protegidas diminished, indicating not only that at depths of up to $15 \mathrm{~m}$ light is not a factor that limits the development of algal turf assemblages, although their composition does vary (Gómez-Cubillos, 2018). Furthermore, the partial mortality of coral tissue in the PNN Tayrona has been greater in deeper waters $(>12 \mathrm{~m})$, particularly during bleaching events or epizootics (Acosta et al., 2018). The accumulation of sediments as a result of resuspension also increases with depth (Bayraktarov, 2013; Bayraktarov et al., 2014a), permitting them to accumulate in the turf fronds in greater concentrations and, as a result, increase the damaging effects of these assemblages when they come into contact with coral tissues.

For the factor exposure to wave action, it was found that coral-turf interactions are more common in protected areas with depths less than $12 \mathrm{~m}$, while in exposed areas, although coral-turf interactions also dominated, the proportion of coral-other categories interactions increased. In deep waters ( $>12 \mathrm{~m}$ ), by contrast, no difference was found in the frequency of interactions between exposed and protected areas. These results suggest that in areas protected from wave action, with a depth of less than $12 \mathrm{~m}$, and where the effect of turbulence is less (Bayraktarov, 2013; Bayraktarov et al., 2014a) and the sediment load increases (Roy, 2004), the effects on corals have been greater. These circumstances favor the development of algal turfs, as the algae trap and retain sediment particles along with detritus in their fronds, and they can then use this material to anchor their holdfasts and grow laterally (Airoldi and Virgilio, 1998; Connell et al., 2014), displacing coral tissues as a result.

\section{Coral-turf interactions}

In overall terms it was found that in the majority of the coral species the selected environmental factors do not exert a significant influence on the frequency of interactions. Furthermore, it was shown that the coverage (\%) of a species is not a covariate of the perimeter that is in interaction with turfs, undermining the hypothesis the greater or lesser the coverage of coral, the greater or lesser the perimeter/frequency of interaction.

These results, alongside the premise that coral-turf interactions usually occur in the wake of the death of coral tissues caused by the actions of physical and biological agents (Rogers et al., 1982; Bythell et al., 1993; Díaz-Pulido and McCook, 2002; Alvarado and Acosta, 2009), permit 
del oleaje con profundidad menor a $12 \mathrm{~m}$ donde el efecto de la turbulencia es menor (Bayraktarov, 2013; Bayraktarov et al., 2014a) y la carga de sedimentos aumenta (Roy, 2004), las afectaciones coralinas han sido mayores y se favorece el desarrollo de los céspedes algales, ya que estas algas atrapan y retienen en sus frondas partículas de sedimentos con detritus, que utilizan como material para anclar sus estructuras de fijación y así poder crecer lateralmente (Airoldi y Virgilio, 1998; Connell et al., 2014), desplazando el tejido coralino.

\section{Interacciones coral-césped}

Se encontró de manera generalizada que los factores ambientales seleccionados no ejercen influencia significativa sobre la frecuencia de interacciones en la mayoría de las especies de coral. Además, se comprobó que la cobertura (\%) de una especie no es covariable de su perímetro en interacción con céspedes, por lo que se desvirtúa la hipótesis de que a mayor o menor cobertura de coral, mayor o menor es el perímetro/frecuencia de interacción.

Estos resultados, junto con la premisa de que una interacción coral-césped usualmente ocurre tras la muerte previa de tejido coralino por acción de agentes físicos y biológicos (Rogers et al., 1982; Bythell et al., 1993; DíazPulido y McCook, 2002; Alvarado y Acosta, 2009), permiten sugerir que la frecuencia actual de interacciones coralcésped es un indicio indirecto de la susceptibilidad particular que tienen cada especie de coral de sufrir lesiones producto del conjunto de perturbaciones que afectan el hábitat de la colonia. Esto complementa la hipótesis de Meesters et al. (1996) de que la susceptibilidad a la mortalidad parcial es específica de la especie de coral, tendencia ya descrita por Ott y Lewis (1972), quienes encontraron que en arrecifes de Barbados la frecuencia de ataque del gusano de fuego Hermodice carunculata, es mayor en colonias de $P$. astreoides que en P. strigosa.

\section{Resultado aparente de la competencia coral-césped}

Del total de casos de interacciones coral-césped identificadas, aparentemente los corales ganan en 37,5\%, pierden en $30,4 \%$ y empatan en $32,1 \%$. Esto sugiere, que en los arrecifes del PNN Tayrona hay una dinámica de reparación de lesiones a pequeña escala, en donde el coral gana y pierde, lo que permite mantener un balance en la proporción de los posibles resultados de estas interacciones. No obstante, al the suggestion to be made that the current frequency of coral-turf interactions is indirect evidence of the particular susceptibility of each coral species to suffering lesions as a result of a combination of perturbations that affect the habitat in which that colony is found. This complements the hypothesis of Meesters et al. (1996) according to which susceptibility to partial mortality is specific to each coral species, a tendency already described by Ott and Lewis (1972), who found that in the reefs of Barbados the frequency of attack by fireworms (Hermodice carunculata), is greater in colonies of $P$. astreoides than in P. strigosa.

\section{Apparent results of coral-turf competition}

Of the total number of identified coral-turf interactions, corals appear to win in $37.5 \%$ cases, lose in $30.4 \%$ and draw in $32.1 \%$. This suggests that in the reefs of the PNN Tayrona a small-scale process exists in which minor lesions are repaired, and in which coral wins and coral loses, meaning that a balance is maintained between the different potential outcomes of these interactions. However, when only the 10 coral species of interest are examined it is apparent that the results of interactions vary with the coral species involved. This coincides with the results of other studies that confirm that coral-turf interactions are highly variable, both in terms of process and results (Jompa and McCook, 2003a), but that the result depends in particular on the mechanisms of competition and the morphology and physiology of the species involved (Díaz-Pulido and McCook, 2002; Jompa and McCook, 2002; Titlyanov et al., 2007; Barott et al., 2012; Corado-Nava et al., 2014; Swierts and Vermeij, 2016). Furthermore, the effects of gradient, depth and exposure on the result of competition, when differentiated by colony organization type and coral species, showed that in this case these selected factors are not reliable predictors of the apparent result of coral-turf competition. This contrasts with the results reported by Airoldi et al. (1995), who concluded that the characteristics of the physical environment in which the competition occurs were relevant.

When the results of coral-turf interactions are analyzed according to type of colony organization, and with the proviso that each component species responds in a different way, it was found that in meandroid and cerioid colonies coral wins was the most frequent result, while in plocoid structures, particularly with $M$. cavernosa, coral loses predominated. This confirms that the type of colony 
analizar sólo las 10 especies de coral de interés, se demostró que el resultado de la competencia varía según la especie de coral. Esto coincide con los resultados de otros estudios que confirman que las interacciones coral-césped son altamente variables tanto en el proceso como en el resultado (Jompa y McCook, 2003a), pero que el resultado depende en particular de los mecanismos de competencia y de la morfología y fisiología de las especies que intervienen (Díaz-Pulido y McCook, 2002; Jompa y McCook, 2002; Titlyanov et al., 2007; Barott et al., 2012; Corado-Nava et al., 2014; Swierts y Vermeij, 2016). Asimismo, los resultados del efecto de los factores gradiente, profundidad y exposición sobre el resultado de la competencia según el tipo de organización colonial y la especie de coral, demostraron que para este caso, los factores seleccionados no son buenos predictores del resultado aparente de la competencia coral-césped, en contraste con lo reportado por Airoldi et al. (1995), quienes encontraron relevantes las características del entorno físico donde se desarrolla la competencia.

Al analizar el resultado de interacciones coralcésped según el tipo de organización colonial, y con la salvedad de que al interior de cada tipo las especies varían en su respuesta, se encontró que en colonias meandroides y cerioides coral gana es el resultado más frecuente, mientras que en formas plocoides, particularmente en $M$. cavernosa el mayor número de casos es coral pierde. Esto confirma que el tipo de organización colonial puede ser en parte determinante en el resultado de la competencia. Por lo anterior, es posible pensar que la selección de los mecanismos de competencia que emplean los corales para luchar en bordes de interacción con céspedes algales son afines entre tipos de organización colonial, y su uso depende del tipo de perturbaciones que están afectando su hábitat. Por su parte, la efectividad de estas estrategias depende de la capacidad de regeneración del tejido lesionado, según sea el tamaño de la lesión (Meesters et al., 1996) y de las tasas de crecimiento (o de evasión/escape) particulares de cada especie (Lang y Chornesky, 1990).

Para interacciones coral-césped aún no se han descrito los posibles mecanismos que intervienen durante la competencia. Por lo tanto, la justificación de la hipótesis arriba planteada se basará en el análisis de los diferentes mecanismos que emplean los corales en interacciones interespecíficas con otros corales (Lang y Chornesky, 1990; McCook et al., 2001), otros organismos bentónicos (Richardson et al., 1979; Karlson, 1980; Chornesky, 1983; López-Victoria et al., 2006) y macroalgas (McCook, 2001; organization can be a partially decisive factor in deciding the results of the competition. For this reason, it appears to be the case that the corals present in different types of colony organization use a similar range of competition mechanisms in their border interactions with algal turfs and that the ones they use depend on the kinds of perturbation affecting their habitat. The effectiveness of these strategies depends on the capacity for regeneration of the damaged tissue in relation to the size of the lesion (Meesters et al., 1996) and the specific growth (or evasion/escape) rates of each species (Lang and Chornesky, 1990).

The possible competition mechanisms involved in coral-turf interactions are yet to be discussed. Thus, the justification of the hypothesis set out above is based on an analysis of the different mechanisms corals employ in their inter-species interactions with other corals (Lang and Chornesky, 1990; McCook et al., 2001), other benthic organisms (Richardson et al., 1979; Karlson, 1980; Chornesky, 1983; López-Victoria et al., 2006) and macroalgae (McCook, 2001; McCook et al., 2001; Nugues et al., 2004), stressing the fact that coral-turf interactions occur at very small scales $(\mathrm{mm})$, given that the contact surfaces offered by the turf algae are minimal.

Corals have developed various physical and chemical mechanisms to defend themselves directly against their competitors (Lang and Chornesky, 1990). A first mechanism involves avoidance of competition through vertical growth (Meesters et al., 1996; López-Victoria et al., 2006), which raises a coral above its competitors in the form of a dome, roof, or lip, impeding their direct action and lateral growth.

The most important of the mechanisms of direct confrontation described in the literature are: extracelenteric digestion, in which mesenterial filaments and sweeper tentacles are used to abrade, sting or destroy enemy soft corals, the production and release into the surrounding seawater of chemical substances that injure opponents that are beyond physical reach, and the secretion of mucus (Richardson et al., 1979; Karlson, 1980; Schoener et al., 1983; Lang and Chornesky, 1990; McCook, 2001; Jompa and McCook, 2002).

In the Caribbean, corals with digestive dominance are the most abundant (Maguire and Porter, 1977). These are generally massive slow-growing forms, with large and small polygonal plocoid and cerioid polyps (Lang and Chornesky, 1990), inasmuch as meandroid corals generally avoid competition by growing upwards (Barnes, 1973; 
McCook et al., 2001; Nugues et al., 2004), precisando que las interacciones coral-césped ocurren en escalas muy pequeñas ( $\mathrm{mm}$ ), ya que las superficies de contacto que ofrecen las algas del césped son mínimas.

Los corales han desarrollado varios mecanismos físicos y químicos para defenderse directamente de sus competidores (Lang y Chornesky, 1990). Un primer mecanismo es el de evadir la competencia a través del crecimiento por altura (Meesters et al., 1996; López-Victoria et al., 2006), que eleva al coral sobre su competidor a manera de un domo, techo o labio, impidiendo la acción directa y avance lateral de su competidor.

Por otro lado, entre los mecanismos de confrontación directa, los más importantes descritos en la literatura son los de digestión extracelentérica a través del uso de filamentos mesentéricos y tentáculos barredores que generan abrasión, escozor o destrucción de los tejidos blandos del oponente, la producción y liberación en el agua de mar circundante de sustancias químicas para lesionar a oponentes que están fuera de alcance, y la secreción de moco (Richardson et al., 1979; Karlson, 1980; Schoener et al., 1983; Lang y Chornesky 1990; McCook, 2001; Jompa y McCook, 2002).

En el Caribe, los corales con dominancia digestiva son los más abundantes (Maguire y Porter, 1977), y generalmente son formas masivas de crecimiento lento, con pólipos poligonales grandes y pequeños de tipo plocoide y cerioide (Lang y Chornesky, 1990), en tanto que los corales de tipo meandroide usualmente evitan la competencia a través del crecimiento por altura (Barnes, 1973; Meesters et al., 1996). Esto es evidente para $P$. strigosa en este estudio y otras observaciones histológicas no publicadas, que produce techos y labios de crecimiento que se elevan ligeramente sobre los céspedes y otros organismos, tendiendo a recubrirlos y así evitar ser afectada. Este mecanismo de crecimiento por altura también se emplea para regenerar lesiones pequeñas, ya que cuando un área de la colonia se daña, el tejido alrededor de la lesión crece hacia adentro de esta a manera de evaginación para recuperar la herida (Meesters et al., 1996). Este proceso fue descrito por Roy (2004) en arrecifes de México para colonias de $S$. siderea expuestas en condiciones con alta carga de sedimentos, y por Meesters et al. (1992) en arrecifes de Curaçao para colonias de P. strigosa. No obstante, el proceso de regeneración del tejido, particularmente de lesiones muy grandes puede que no se complete, dejando este espacio disponible para que los céspedes se afiancen y luego continúen avanzando, pero especies meandroides más resistentes como Meandrina meandrites y Mycetophyllia
Meesters et al., 1996). This was evident in the case of $P$. strigosa in this study and in other unpublished histological observations, which produces growth roofs and lips that rise slightly above the turfs and other organisms, tending to cover them and in this manner avoid the negative effects of competition. This vertical growth mechanism is used to regenerate small lesions, since once an area of the colony has been damaged the tissue surrounding the lesion grows inwards in a process of evagination in order to repair the wound (Meesters et al., 1996). This process was described by Roy (2004) for colonies of S. siderea exposed to conditions with high sediment loads in reefs in Mexico, and by Meesters et al. (1992) for reefs in Curaçao in colonies of $P$. strigosa. However, particularly in cases of very large lesions, the process of tissue regeneration may remain incomplete, leaving the damaged areas available for turfs to establish themselves and continue their advance. However, the more resistant species of meandroids, such as Meandrina meandrites and Mycetophyllia spp. have developed a greater regeneration potential, in order to reduce the damage caused by superficial and peripheral interactions (Meesters et al., 1996).

In sum, in frequently disturbed reefs, a strategy to evade coral-turf competition through vertical growth is more successful than strategies based on extracelenteric digestion (Maguire and Porter, 1977). This argument helps explain why in the PNN Tayrona the meandroid and cerioid colonies (with some exceptions in the interior of each kind of colony, e.g., $O$. annularis in the case of plocoids and $M$. meandrites for meandroids) presented a larger number of coral-does-not-lose interactions (wins + neutral), because they use the mechanism. However, the increase in the frequency and intensity of the perturbations, could have the effect of limiting recovery times and the ability of species to defend themselves, leading to future changes in the structure of the coral communities. This was documented by Loya et al. (2001) in the reefs off the southern coast of the Japanese island of Sesoko, where, following an episode of mass bleaching, species with more successful competitive strategies predominated.

This study contributes to an improved understanding of coral-turf interactions, and outlines two general approaches that have the potential to help understand and quantify biological processes that occur in reef communities, at least those found in the NNP Tayrona in the Colombian Caribbean. The first is that, more than its size and coverage, it is the species of coral (frequently 
spp. han desarrollado potenciales de regeneración más altos a fin de reducir los daños por interacciones en superficie y periferia (Meesters et al., 1996).

En resumen, en arrecifes frecuentemente perturbados, la evasión de la competencia coral-césped por crecimiento en altura es una estrategia competitiva más exitosa respecto a la obtenida por la digestión extracelentérica (Maguire y Porter, 1977). Este argumento permite entender porque en los arrecifes del PNN Tayrona las colonias meandroides y cerioides (con algunas excepciones al interior de cada tipo, e.g., O. annularis para plocoides, $M$. meandrites para meandroides) presentaron un mayor número de casos de coral no pierde (gana + neutra), ya que usan este mecanismo. No obstante, el aumento en la frecuencia e intensidad de las perturbaciones, podrían limitar los tiempos de recuperación y la capacidad de defensa de las especies, provocando a futuro cambios en la estructura de las comunidades coralinas. Esto fue documentado por Loya et al. (2001) en los arrecifes de la costa sur de la isla de Sesoko en Japón, donde prevalecieron, tras un evento de blanqueamiento masivo, aquellas especies con estrategias competitivas más exitosas.

En suma, este estudio contribuye a una mejor comprensión de las interacciones coral-césped, y propone dos esquemas generales que podrían ayudar a comprender y cuantificar procesos biológicos en las comunidades arrecifales, al menos del PNN Tayrona en el Caribe colombiano. Uno es que la especie de coral (con frecuencia en asocio con el tipo de organización colonial), más que su tamaño y cobertura, son factores determinantes en la frecuencia y el resultado de interacciones coral-césped. El otro es que esto implica que a futuro sea probable que la composición y complejidad estructural de estos arrecifes también cambie en respuesta al aumento de perturbaciones que incrementen los escenarios de competencia entre corales hermatípicos y céspedes algales, y los potenciales resultados de estas interacciones según las estrategias empleadas los corales.

\section{CONCLUSIONES}

En los arrecifes del PNN Tayrona el competidor más frecuente de corales hermatípicos son los céspedes algales, y las interacciones coral-césped son más frecuentes en arrecifes cercanos a Santa Marta, y en áreas protegidas del oleaje con mayor profundidad. Esto refleja el efecto residual de la trayectoria de perturbación a la que han estado sometidos estos arrecifes. Empero, las diferencias en la frecuencia de interacciones entre bahías y estaciones in association with the way the colony is organized) that is decisive in the frequency and results of coral-turf interactions. The other is that this implies that in the future it is likely that the composition and complexity of these reefs will also change, in response to escalated levels of disturbance, which will increase the number of competition scenarios between hermatypic corals and algal turfs, and the potential results of these interactions that result from the strategies employed by the corals.

\section{CONCLUSIONS}

In the reefs of the PNN Tayrona the most frequent competitor of hermatypic corals are algal turfs, and coralturf interactions are more frequent in reefs that are close to Santa Marta, and in deeper locations that are protected from wave action. This reflects a residual effect of the perturbation gradient to which these reefs have already been subjected. However, the differences in the frequency of interactions between bays and stations confirms that these perturbations affect each reef in a different way.

The frequency of coral-turf interactions depends on the coral species involved and of its susceptibility to losing coral tissue as a result of the perturbations affecting the reef they inhabit. The result of the competition depends on the coral species involved, in part association with the type of colony organization: meandroid and cerioid colonies being the most successful competitors because of the vertical growth strategies they employ. Plocoid colonies, on the other hand, are more likely to lose. By contrast, environmental factors (gradient, depth and exposure) do not seem to exert a major influence on the frequency and apparent results of these interactions.

Thus, the results of this research predict that the analysis of the historical data on coral cover in the PNN Tayrona should demonstrate greater or lesser degrees of loss in coverage by species from place to place, depending on the distribution of the conditions that are deleterious to coral and favorable to turfs. In addition, the same perturbation tendencies will continue to occur in the future, in the long term favoring, with some exceptions, meandroid and cerioid corals over plocoids.

\section{ACKNOWLEDGEMENTS}

This research was made possible by the support and financial backing of Universidad Nacional de Colombia, Sede Caribe and the Instituto de Estudios en Ciencias del 
confirma que estas perturbaciones afectan de manera diferencial cada arrecife.

La frecuencia de interacciones coral-césped depende de la especie de coral involucrada y de su susceptibilidad a perder tejido coralino producto del conjunto de perturbaciones que afectan el arrecife donde habita. Por su parte, el resultado de la competencia depende de la especie de coral, en parte en asocio con el tipo de organización colonial, siendo las colonias meandroides y cerioides competidores más exitosos, debido al mecanismo de evasión por crecimiento en altura; mientras que las colonias de tipo plocoide son más propensas a perder. Por el contrario, los factores ambientales (gradiente, profundidad y exposición) parecen no desempeñar un papel preponderante sobre la frecuencia y resultado aparente de estas interacciones.

En tal sentido, a partir de los resultados de esta investigación se predice que el análisis de datos históricos de la cobertura coralina del PNN Tayrona debe mostrar pérdidas mayores o menores en cobertura por especie según el lugar, de acuerdo con la distribución de las condiciones deletéreas para corales y favorecedoras de los céspedes. Además, en el futuro continuarán las mismas tendencias de perturbación, favoreciendo en el largo plazo, con algunas excepciones, a especies de coral de tipo meandroide y cerioide, sobre las plocoides.

\section{AGRADECIMIENTOS}

Esta investigación se realizó gracias al apoyo y los recursos financieros de la Universidad Nacional de Colombia, Sede Caribe y el Instituto de Estudios en Ciencias del Mar - Cecimar, a través de fondos obtenidos en la Convocatoria Nacional para el Apoyo a Proyectos de Investigación y Creación Artística de la Universidad Nacional de Colombia 2017-2018 (código Hermes 39161). Igualmente se agradece a la Unidad Administrativa Especial del Sistema de Parques Nacionales Naturales - Parque Nacional Natural Tayrona (UAESPNN PNN Tayrona) por incluir este proyecto de investigación dentro de su portafolio, y al Instituto de Investigaciones Marinas y Costeras - Invemar por permitirnos participar y financiar los costos de buceo durante las salidas de campo del grupo SIMAC en la campaña de octubre de 2016. Los resultados son parte de la tesis de MCGC como requisito para obtener el título de Magister en Ciencias-Biología, Línea Biología Marina de la Universidad Nacional de Colombia, Sede Caribe. Contribución $\mathrm{N}^{\circ} 493$ del Cecimar.
Mar - Cecimar, provided by the Convocatoria Nacional para el Apoyo a Proyectos de Investigación y Creación Artística of Universidad Nacional de Colombia 2017-2018 (code: Hermes 39161). The authors also wish to express their gratitude to the Unidad Administrativa Especial del Sistema de Parques Nacionales Naturales - Parque Nacional Natural Tayrona (UAESPNN - PNN Tayrona) for including this research project in its portfolio, and to the Instituto de Investigaciones Marinas y Costeras - Invemar for giving us permission to participate in the field visits organized by the SIMAC groups during its October 2016 campaign, and for covering the diving costs. The results form a part of the MCGC thesis presented achieve the title of Master in Biological Sciences - Marine Biology [Magister en Ciencias-Biología, Línea Biología Marina] awarded by Universidad Nacional de Colombia, Sede Caribe. Cecimar Contribution $\mathrm{N}^{\circ} 493$. 


\section{BIBLIOGRAFÍA / LITERATURE CITED}

Acero-P., A., D. Bustos-Montes, P. Pabón-Quintero, C. J. Polo-Silva and A. Sanjuan-Muñoz, A. 2019. Feeding habits of Pterois volitans: A real threat to Caribbean coral reef biodiversity. 269-314. In: Makowski C. y Finkl, C. (Eds.). Impacts of Invasive Species on Coastal Environments, Coastal Research Library. Vol 29. Springer, Cham.

Acosta, A., D, González, E. Navas y L. Sánchez. 2018. Estado de las formaciones coralinas del Parque Nacional Natural Tayrona años 2008 - 2018. Inf. Técn. Mon. Ecosist. ITF \# 1. Invemar. Santa Marta. 94 p.

Agresti, A. 2002. Categorical data analysis. Wiley-Interscience a John Wiley y Sons, inc., Publication (Eds.). 2 editions. Florida. 721 p.

Airoldi, L. 2003. The effects of sedimentation on rocky coast assemblages. Oceanogr. Mar. Biol. Annu. Rev., 41: 161-236.

Airoldi, L. and M. Virgilio. 1998. Responses of turf-forming algae to spatial variations in the deposition of sediments. Mar. Ecol. Prog. Ser., 165: 271-282.

Airoldi,L., F. Rindi and F. Cinelli. 1995. Structure, seasonal dynamics and reproductive phenology of a filamentous turf assemblage on a sediment influenced, rocky subtidal shore. Bot. Mar.., 38(3): 227-237.

Alvarado, E. y A. Acosta. 2009. Lesiones naturales y regeneración de tejido en ramets del coral Montastrea annularis (Scleractinia: Faviidae) en un arrecife degradado del Caribe Colombiano. Rev. Biol. Trop., 57(4): 939-954.

Aronson R. B. and W. F. Precht. 2001. White-band disease and the changing face of Caribbean coral reefs. Hydrobiologia, 460: 25-38.

Barnes, D. J. 1973. Growth in colonial scleractinians. Coral Reef Project - Papers in memory of Dr. Thomas F. Goureau, 12 (Eds.). Queensland - Australia. 19 p.

Barott, K. L., J. Smith, E. Dinsdale, M. Hatay, S. A. Sandin and F. Rohwer. 2009. Hyperspectral and physiological analyses of coral-algal interactions. PLoS One, 4(11): e8043.

Barott, K. L., G. J. Williams, M. J. A.Vermeij, J. Harris, J. E. Smith, F. L. Rohwer and S. A. Sandin. 2012. Natural history of coral-algae competition across a gradient of human activity in the Line Islands. Mar. Ecol. Prog. Ser., 460: 1-12.

Bayraktarov, E. 2013. Effects of seasonality and upwelling on coral reef functioning in Tayrona National Natural Park, Colombian Caribbean. Ph.D. Thesis, University of Bremen, Germany. 247 p.

Bayraktarov, E. and C. Wild. 2014. Spatiotemporal variability of sedimentary organic matter supply and recycling processes in coral reefs of Tayrona National Natural Park, Colombian Caribbean. Biogeosciences, 11: 2977-2990,

Bayraktarov, E., M. L. Bastidas and C. Wild, 2014a. The physical environment in coral reefs of the Tayrona National Natural Park (Colombian Caribbean) in response to seasonal upwelling. Bol. Invest. Mar. Cost., 43(1): 137-157.

Bayraktarov, E., V. Pizarro and C. Wild. 2014b. Spatial and temporal variability of water quality in the coral reefs of Tayrona National Natural Park, Colombian Caribbean. Environ. Monit. Asses., 186(6): 3641-3659.

Bender-Champ, D., G. Díaz-Pulido and S. Dove. 2014. Warming and acidification promote cyanobacterial dominance in turf algal assemblages. Mar. Ecol. Prog. Ser., 517: 271-284.

Birrell, C. L., L. J. McCook and B. L. Willis. 2005. Effects of algal turfs and sediment on coral settlement. Mar. Pollut. Bull., 51: 408-414.

Birrell, C. L., L. J. McCook, B. L. Willis and G. Díaz-Pulido. 2008. Effects of benthic algae on the replenishment of corals and the implications for the resilience of coral reefs. Oceanogr. Mar. Biol. Annu. Rev., 46: 25-63.

Bruggemann, J. H., M. W. Kuyper and A. M. Breeman. 1994. Comparative analysis of foraging and habitat use by the sympatric Caribbean parrotfish Scarus vetula and Sparisoma viride (Scaridae). Mar. Ecol. Prog. Ser., 112: 51-66.

Bula-Meyer, G. 1990. Altas temperaturas estacionales del agua como condición disturbadora de las macroalgas del Parque Nacional Tairona, Caribe colombiano: Una hipótesis. An. Inst. Invest. Mar. Punta Betín, 19-20: 9-21.

Burkepile, D. E. and M. E. Hay. 2010. Impact of herbivore identity on algal succession and coral growth on a Caribbean reef. PLoS One, 5(1): e8963.

Bythell, J. C., E. H. Gladfelter and M. Bythell, 1993. Chronic and catastrophic natural mortality of three common Caribbean reef corals. Coral Reefs, 12 : 143-152.

CARICOMP. 2001. Methods manual levels 1 and 2: Manual of Methods for mapping and monitoring of physical and biological parameters in the coastal zone of the Caribbean. CARICOMP Data Management Center, Univ. West Indies (Eds.). Kingston. 93 p.

Chornesky, E. A. 1983. Induced development of sweeper tentacles on the reef coral Agaricia agaricites: a response to direct competition. Biol. Bull., 165(3): 569-581.

Colwell, R. K. 2013. EstimateS version 9.1 Statistical estimation of species richness and shared species from samples (software and user's guide). Freeware for Windows and Mac OS, http://viceroy.eeb.uconn.edu/estimates

Connell, J. H. 1997. Disturbance and recovery of coral assemblages. Coral Reefs, 16(1): 101-113.

Connell, S. D., M. S. Foster and L. Airoldi. 2014. What are algal turfs? Towards a better description of turfs. Mar. Ecol. Prog. Ser., 495: $299-307$.

Corado-Nava, N. A., D. Rodríguez, D. y G. Rivas. 2014. Efecto de la colonización de los céspedes algales en el crecimiento de Pocillopora capitata (Anthozoa: Scleractinia) en el Pacífico tropical mexicano. Rev. Mex. Biodivers., 85: 1086-1092.

Cyronaka, T. and B. D. Eyrea. 2016. The synergistic effects of ocean acidification and organic metabolism on calcium carbonate $\left(\mathrm{CaCO}_{3}\right)$ dissolution in coral reef sediments. Mar Chem.,: doi: 10.1016/j.marchem.2016.05.001. 
De la Fuente, S. 2011. Regresión logística. Facultad de Ciencias Económicas y Empresariales, Universidad Autónoma de Madrid (Eds.). Madrid. 29 p.

Díaz, J. M., L. M. Barrios, M. H. Cendales, J. Garzón-Ferreira, J. Geister, M. López-Victoria, G. H. Ospina, F. Parra-Velandia, J. Pinzón, B. Vargas-Ángel, F. A. Zapata y S. Zea. 2000. Áreas coralinas de Colombia. Invemar. Ser. Publ. Esp. 5 Santa Marta. 179 p.

Díaz-Pulido, G. and J. Garzón-Ferreira. 2002. Seasonality in algal assemblages on up welling-influenced coral reefs in the Colombian Caribbean. Bot. Mar., 45: 284-292.

Díaz-Pulido, G. and L. J. McCook. 2002. The fate of bleached corals: patterns and dynamics of algal recruitment. Mar. Ecol. Prog. Ser., 232: 115-128.

Franco-Herrera, A. 2005. Oceanografía de la ensenada de Gaira: El Rodadero, más que un centro turístico en el Caribe colombiano. Fund. Univ. Bogotá Jorge Tadeo Lozano, Bogotá. 56 p.

Fricke, A., M. Teichberg, S. Beilfuss and K. Bischof. 2011. Succession patterns in algal turf vegetation on a Caribbean coral reef. Bot. Mar., 54(2): 111-126. Friedlander, A., R. Navas, M. Prada, A. Rodríguez-Ramírez and S. Zea. 2014. Part II. Reports for individual countries and territories - Colombia. 196 -201. In: Jackson J. B. C., M. K. Donovan, K. L. Kramer y V. V. Lam (Eds.). 2014. Status and trends of Caribbean coral reefs: 1970 - 2012. Global Coral Reef Monitoring Network, IUCN, Gland, Switzerland. Washington. 306 p.

Garzón-Ferreira, J. and A. Rodríguez-Ramírez. 2010. SIMAC: development and implementation of a coral reef monitoring network in Colombia. Rev. Biol. Trop., 58(1): 667-680.

Garzón-Ferreira, J. and S. Zea. 1992. A mass mortality of Gorgonia ventalina (Cnidaria: Gorgoniidae) in the Santa Marta area, Caribbean coast of Colombia. Bull. Mar. Sci., 50 (3): 522-526.

Garzón-Ferreira, J., M. C. Reyes-Nivia y A. Rodríguez-Ramírez, A. 2002. Manual de métodos del SIMAC - Sistema Nacional de Monitoreo de Arrecifes Coralinos en Colombia. Inf. Final Invemar. Santa Marta. 61 p.

Gladfelter W. B. 1982. White-band disease in Acropora palmata: implications for the structure and growth of shallow reefs. Bull Mar Sci., 32:639-643.

Gómez Cubillos, C. 2018. Interacciones coral-césped de algas y sus efectos en la comunidad coralina en el área de Santa Marta, Caribe colombiano. Tesis M.Sc., Ciencias-Biología, Línea Biología Marina, Universidad Nacional de Colombia, Sede Caribe.

Gómez-Lemos L.A and G. Díaz-Pulido. 2017. Crustose coralline algae and associated microbial biofilms deter seaweed settlement on coral reefs. Coral Reefs, 36(2): 453-462.

Gorgula, S. K. and S. D. Connell. 2004. Expansive covers of turf-forming algae on human-dominated coast: The relative effects of increasing nutrient and sediment loads. Mar. Biol., 145(3): 613-619.

Gowan, J. C., J. S. Tootell and R. C. Carpenter. 2014. The effects of water flow and sedimentation on interactions between massive Porites and algal turf. Coral Reefs, 33(3): 651-663.

Guisande, C., A. Vaamonde y A. Berreiro. 2013. Tratamiento de datos con R, Statistica y SPSS. Ediciones Díaz de Santos (Eds.). 997 p.

Haas, A., M. el-Zibdah and C. Wild. 2010. Seasonal monitoring of coral-algae interactions in fringing reefs of the Gulf of Aqaba, Northern Red Sea. Coral Reefs, 29: 93-103.

Hamilton, S. L., J. E. Smith, N. N. Price and S. A. Sandin. 2014. Quantifying patterns of fish herbivory on Palmyra Atoll (USA), an uninhabited predatordominated central Pacific coral reef. Mar. Ecol. Prog. Ser., 501: 141-155.

Harris, J. L. 2015. The ecology of turf algae on coral reefs. Ph.D. Thesis, University of California. 201 p.

Harris, J. L., L. S. Lewis and J. E. Smith. 2015. Quantifying scales of spatial variability in algal turf assemblages on coral reefs. Mar. Ecol. Prog. Ser., 532: $41-57$. Heyward, A. J. and A. P. Negri. 1999. Natural inducers for coral larval metamorphosis. Coral Reefs, 18(3): 273-279.

Hughes, T. P. 1994. Catastrophes, phase shifts, and large-scale degradation of a Caribbean coral reef. Science, 265(5178): 1547-1551.

Hughes, T. P. and J. H. Connell. 1999. Multiple stressors on coral reefs: A long-term perspective. Limnol. Oceanogr., 44(3-2): 932-940.

Hughes, T. P., M. J. Rodríguez, D., R. Bellwood, D. Ceccarelli, O. Hoegh-Guldberg, L. McCook, N. Moltschaniwskyj, M. S. Pratchett, R. S. Steneck and B. Willis. 2007. Phase shifts, herbivory and the resilience of coral reefs to climate change. Curr. Biol., 17: 360-365.

Johnson, M. D., S. Comeau, C. A. Lantz and J. E. Smith. 2017. Complex and interactive effects of ocean acidification and temperature on epilithic and endolithic coral-reef turf algal assemblages. Coral Reefs 36(4): 1-12.

Jompa, J. and L. J. McCook. 2002. The effect of herbivory on competition between a macroalga and a hard coral. J. Exp. Mar. Biol. Ecol., 271: 25-39.

Jompa J. and L. J. McCook. 2003a. Contrasting effects of turf algae on corals: massive Porites spp. are unaffected by mixed-species turfs, but killed by the red alga Anotrichium tenue. Mar. Ecol. Prog. Ser., 258: 79-86.

Jompa J. and L. J. McCook. 2003b. Coral-algal competition: macroalgae with different properties have different effects on corals. Mar. Ecol. Prog. Ser., 258: 87-95. Karlson, R. H. 1980. Alternative competitive strategies in a periodically disturbed habitat. Bull. Mar. Sci., 30(4): 894-900.

Kennelly, S. J. 1987. Inhibition of kelp recruitment by turfing algae and consequences for an Australian kelp community. J. Exp. Mar. Biol. Ecol., 112: 49-60. Lang, J. C. and E. A. Chornesky. 1990. Competition between scleractinian reef corals: a review of mechanisms and effects. 209-252. In: Dubinsky, Z. (Ed.) Ecosystems of the world, 25. Coral reefs. Amsterdam. 521 p.

Ledlie, M. H., N. A. J. Graham, J. C. Bythell, S. K. Wilson, S. Jennings, N. V. C. Polunin and J. Hardcastle. 2007. Phase shifts and the role of herbivory in the resilience of coral reefs. Coral Reefs, 26: 641-653. 
Lessios, H. A., D. R. Robertson and J. D. Cubit. 1984. Spread of Diadema mass mortality through the Caribbean. Science, 226: 335-337.

Littler, M. M., D. S. Littler and B. L. Brooks. 2006. Harmful algae on tropical coral reefs: bottom-up eutrophication and top-down herbivory. Harmful Algae., 5:565-585.

López-Victoria, M., S. Zea and E. Weil. 2006. Competition for space between encrusting excavating Caribbean sponges and other coral reef organisms. Mar. Ecol. Prog. Ser., 312: 113-121.

Loya. Y., K. Sakai, K. Yamazato, Y. Nakano, H. Sambali and R. van Woesik. 2001. Coral bleaching: The winners and losers. Ecol. Lett., 4: 122-131.

Maguire, L. and J. Porter. 1977. A spatial model of growth and competition strategies in coral communities. Ecol. Modell., 3: $249-271$.

Márquez, J. C. and S. Zea. 2012. Parrotfish mediation in coral mortality and bioerosion by the encrusting, excavating sponge Cliona tenuis. Mar. Ecol., 33: 417-426.

Martínez, S. y A. Acosta. 2005. Cambio temporal en la estructura de la comunidad coralina del área de Santa Marta - Parque Nacional Natural Tayrona (Caribe colombiano). Bol. Invest. Mar. Cost., 34: 161-191.

McCook, L. J. 2001. Competition between corals and algal turfs along a gradient of terrestrial influence in the nearshore central Great Barrier Reef. Coral Reefs, 19: 419-425.

McCook, L. J., J. P. Jompa and G. Díaz-Pulido. 2001. Competition between corals and algae on coral reefs: a review of evidence and mechanisms. Coral Reefs, 19: 400-417.

McManus, J. W. and J. F. Polsenberg. 2004. Coral-algal phase shifts on coral reefs: ecological and environmental aspects. Prog. Oceanogr., 60: $263-279$.

Meesters, E. H., A. Bos and G. J. Gast. 1992. Effects of sedimentation and lesion position on coral tissue regeneration. 671-678. In: Proceedings of the Seventh International Coral Reef Symposium (Eds.). Guam-Micronesia. 640 p.

Meesters, E. H., I. Wesseling and R. P. M. Bak. 1996. Partial mortality in three species of reef-building corals and the relation with colony morphology. Bull. Mar. Sci., 58(3): 838-852.

Navas-Camacho, R., D. L. Gil-Agudelo, A. Rodríguez-Ramírez, M. C. Reyes-Nivia and J. Garzón-Ferreira. 2010. Coral diseases and bleaching on Colombian Caribbean coral reefs. Rev. Biol. Trop., 58 (Suppl. 1): 95-106.

Nugues, M. M., L. Delvoye, P. Rolf and M. Bak. 2004. Coral defense against macroalgae: differential effects of mesenterial filaments on the green alga Halimeda opuntia. Mar. Ecol. Prog. Ser., 278: 103-114.

Ogilvie, M. M. 1896. Microscopic and systematic study of madreporian types of corals. Philosophical Transact. Roy. Soc. London, series B, 187, 270 p.

Ott, B. and J. B. Lewis. 1972. The importance of the gastropod Coralliophila abbreviata (Lamarck) and the polychaete Hermodice carunculata (Pallas) as coral reef predators. Can. J. Zool., 50: 1651-1656.

Preskitt, L. B., P. S. Vroom and C. M. Smith. 2004. A rapid ecological assessment (REA) quantitative survey method for benthic algae using photoquadrats with scuba. Pac. Sci., 58(2): 201-209.

Ramírez, G. 1983. Características físico-químicas de la bahía de Santa Marta (agosto 1980 - Julio 1981). An. Inst. Invest. Mar. Punta Betín., 13: 111-121.

Reyes, J., N. Santodomingo y P. Flórez. 2010. Corales escleractíneos de Colombia. Invemar, Serie de Publicaciones Especiales, No. 14. Santa Marta. 246 p. Richardson, C. A., P. Dustan y J. C. Lang. 1979. Maintenance of living space by sweeper tentacles of Montastraea cavernosa, a Caribbean reef coral. Mar. Biol., 55: 181-186.

Rogers, C. S., T. H. Suchanek y F. A. Pecora. 1982. Effects of hurricanes David and Frederic (1979) on shallow Acropora palmata reef communities: St. Croix, U.S. Virgin Islands. Bull. Mar. Sci., 32(2): $532-548$.

Roy, R. E. 2004. Turf algal/sediment (TAS) Mats: A chronic stressor on scleractinian corals. Ph.D. Thesis, University of Texas at Austin. 191 p.

Sandin, S. A., J. E. Smith, E. E. Demartini, E. A. Dinsdale, S. D. Donner, A. M. Friedlander, T. Konotchick, M. Malay, J. E. Maragos, D. Obura, O. Pantos, G. Paulay, M. Richie, F. Rohwer, R. E. Schroeder, S. Walsh, J. B. C. Jackson, N. Knowlton and E. Sala. 2008. Baselines and degradation of coral reefs in the Northern Line Islands. PLoS One., 3(2): e1548.

Schoener, T. W. 1983. Field experiments on interspecific competition. Amer. Nat., 122(2): 240-285.

Sokal, R. R. and F. J. Rohlf. 1981. Biometry. The principles and practice of statistics in biological research. 2nd edition. W. H. Fremen. San Francisco. 867 p. Sousa, W. P. 1979. Experimental investigations of disturbance and ecological succession in a rocky intertidal algal community. Ecol. Monogr., 49(3): 227-254.

Steneck, R. S. 1997. Crustose corallines, other algal functional groups, herbivores and sediments: complex interactions along reef productivity gradients. 695700. In: Lessios, H.A. and I. G. Macintyre (eds.) Proc. 8th Intern. Coral Reef Symp. Vol. 1. Smithsonian Tropical Research Institute, Panama. 2119 p.

Swierts, T. and M. J. A. Vermeij. 2016. Competitive interactions between corals and turf algae depend on coral colony form. PeerJ., 4: e1984 https://doi. org/10.7717/peerj.1984.

Titlyanov, E. A., I. M. Yakovleva and T. V. Titlyanova. 2007. Interaction between benthic algae (Lyngbya bouillonii, Dictyota dichotoma) and scleractinian coral Porites lutea in direct contact. J. Exp. Mar. Biol. Ecol., 342: 282 - 291.

Underwood, A. 1997. Experiments in ecology: their logical design and interpretation using analysis of variance. Cambridge University Press. New York. 504 p. Vega-Sequeda, J., A. Rodríguez-Ramírez y M. C. Reyes-Nivia. 2008. Formaciones coralinas del área de Santa Marta: estado y patrones de distribución espacial de la comunidad bentónica. Bol. Invest. Mar. Cost., 37(2): 87-105. 
Vermeij, M. J. A., M. L. Dailer, S. M. Walsh, M. K. Donovan and C. M. Smith. 2010. The effects of trophic interactions and spatial competition on algal community composition on Hawaiian coral reefs. Mar. Ecol., 31: 291-299.

Werding, B. y H. Sánchez. 1988. Deterioro observado en las formaciones coralinas de la Bahía de Santa Marta, Colombia. An. Inst. Invest. Mar. Punta Betín, 18: 9-16.

Werding, B. and H. Sánchez. 1989. The coral formations and their distributional pattern along a wave exposure gradient in the area of Santa Marta, Colombia. Medio Amb., 10(2) 61-68.

Zea, S. 1993. Cover of sponge and other sessile organism in rocky and coral reef habitats of Santa Marta, Colombian Caribbean Sea. Carib. J. Sci., 29(1-2): $75-88$.

Zea, S. 1994. Patterns of coral and sponge abundance in stressed coral reefs at Santa Marta, Colombian Caribbean. 257-264. In: Van Soest, R., Van Kempen, T. and J. C. Bracekman (eds.), Proc. $4^{\text {th }}$ Intern. Porifera Congress. Amsterdam. 544 